\title{
Relatório brasileiro sobre desenvolvimento social
}

\section{LUIZ FELIPE LAMPREIA}
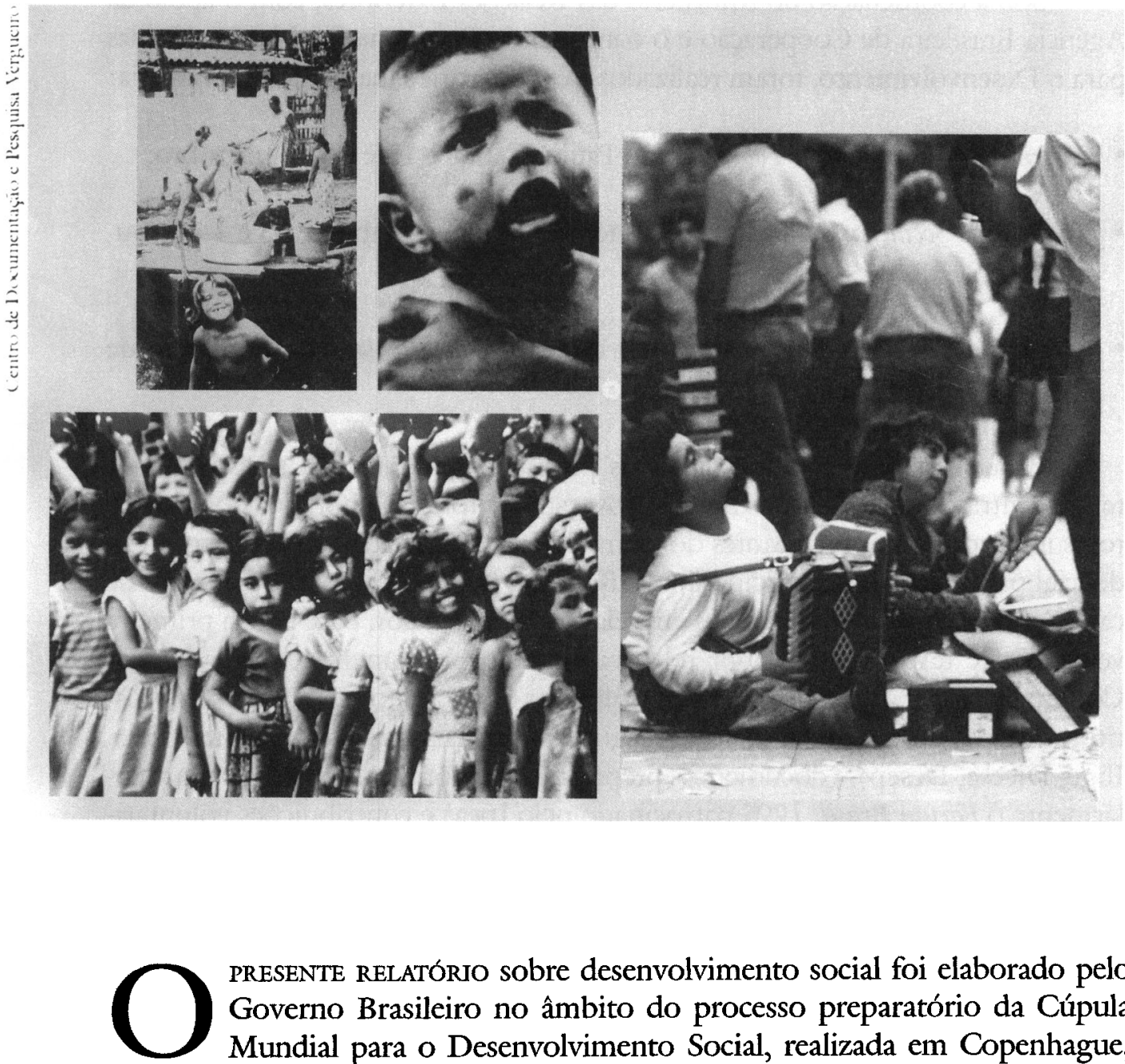

PRESENTE RELATÓRIO sobre desenvolvimento social foi elaborado pelo Governo Brasileiro no âmbito do processo preparatório da Cúpula Mundial para o Desenvolvimento Social, realizada em Copenhague, em março de 1995.

Luiz Felipe Lampreia é ministro das Relações Exteriores do Brasil 
Sem pretender ser um retrato abrangente da situação social no Brasil, o Relatório foi concebido de modo a contemplar os três temas centrais da Cúpula - alívio e redução da pobreza, expansão do emprego produtivo e integração social. Esses temas balizam a estrutura do texto, bem como as informaçóes dele constantes.

De extrema relevância para a forma final do Relatório foi o processo que the deu origem. Constitui uma síntese de abrangente processo de debates, que contou com a participação ampla e democrática dos segmentos sociais interessados.

Sob a coordenação do Ministério das Relações Exteriores, com o apoio da Agência Brasileira de Cooperação e o concurso do Programa das Naçóes Unidas para o Desenvolvimento, foram realizados três seminários, na seguinte seqüência:

- Desenvolvimento Social e Pobreza. São Paulo, Cebrap, 15 e 16 de setembro;

- Integração Social, anos 90. Recife, Fundação Joaquim Nabuco, 13 e 14 de outubro;

- Desenvolvimento Social e Trabalho. Rio de Janeiro desafio dos, IBGE, 10 e 11 de novembro.

Para proporcionar discussão mais profunda e organizada a respeito dos temas centrais de cada um dos Seminários, estudos foram elaborados por consultores indicados pelos integrantes do Comitê Nacional, criado por Decreto Presidencial para preparar a participação do Brasil na referida Cúpula. Os debates de cada Seminário foram sumariados em relatórios específicos, base para a primeira versão deste texto, redigida por relatora também previamente designada pelo Comitê Nacional. Além disso, foram utilizados documentos elaborados por institutos de pesquisa e coleta de dados - governamentais ou independentes (Ipea, Ibge, Dieese, Desep) - documentos preparados para outros seminários (particularmente o Fórum Brasil, 1995 patrocinado pelo Ipea) e contribuiçóes voluntárias. Dessa forma, o Relatório Nacional brasileiro busca refletir menos a visão unilateral do Governo Federal do que posições decorrentes do diálogo democrático em curso entre o Governo e a sociedade civil brasileira, na busca de soluçóes para os problemas nacionais.

O Relatório oficial do Brasil, consensualmente aprovado pelos integrantes do Comitê Nacional para a preparação da participação brasileira na Cúpula Mundial para o Desenvolvimento Social, constitui passo importante no debate sobre temas sociais, o qual não deve se restringir a um diagnóstico da situação social no Brasil, mas também identificar princípios a guiar as ações concretas a serem implementadas nessa área. $\mathrm{O}$ diálogo a esse respeito deverá estender-se até a Cú- 
pula de Copenhague e aprofundar-se depois dela, consolidando-se como prática cotidiana na sociedade brasileira.

\section{Caracterização geral}

Por suas características de país continental $\left(8,5\right.$ milhóes de $\left.\mathrm{km}^{2}\right)$, com tudo o que isso significa em termos de diversidade e complexidade, o Brasil defrontase com desafios bastante peculiares no que tange à formulação de políticas de desenvolvimento social. Para melhor caracterizar esses desafios, esta primeira seção expõe os dados gerais mais relevantes.

No tocante à divisão político-administrativa, a República Federativa do Brasil é constituída por 26 estados, divididos em 4.974 municípios, além do Distrito Federal (Brasília).

A população brasileira atual é de 156.300 .000 pessoas (dados de 1992). Isto indica um crescimento populacional, na última década, de $23,3 \%$, inferior ao crescimento da década de 70 , da ordem de $27,7 \%$.

A distribuição populacional pelo território é altamente diferenciada, como se pode depreender dos dados relativos às cinco macrorregióes - Norte, Nordeste, Sudeste, Sul e Centro-Oeste -, definidas em $1970 \mathrm{e} \mathrm{em}$ vigor para fins de sistematização de dados. Enquanto na região Norte $(\mathbf{4 5 , 2 6 \%}$ do território nacional e 5,90\% da população) a densidade demográfica é de 2,39 habitantes por $\mathrm{km}^{2}$, na região Sudeste $(10,85 \%$ do território e $43,5 \%$ da população) é de 73,61 habitantes por $\mathrm{km}^{2}$. Na região Nordeste $(18,27 \%$ da área total e $28,5 \%$ da população), a densidade demográfica é de 29,07 habitantes por $\mathrm{km}^{2}$, e na região Centro-Oeste $(18,86 \%$ da área total e $6,80 \%$ da população), bastante inferior, de 6,62 habitantes por $\mathrm{km}^{2}$. Por fim, a região Sul, a menor em termos de extensão $(6,76 \%$ do território nacional) abarca $15,2 \%$ da população, o que determina uma densidade demográfica de 41,28 habitantes por $\mathrm{km}^{2}$ (tabela 1 ). Some-se a isso o fato de que, apesar de a população brasileira ser de caráter eminentemente urbano ( $75 \%$ da população), dos seus quase cinco mil municípios $45,7 \%$ são de pequeno porte (até 10.000 habitantes) - certamente um fator a ser levado em conta no enfrentamento da pobreza mediante políticas públicas descentralizadas.

Um indicador econômico relevante é a contribuição regional para o PIB. Para a indicação básica da magnitude das atividades econômicas tem-se que o PIB de 1990 foi da ordem de US\$ 464,6 bilhões. Dados de 1985 apresentam a seguinte distribuição: a região Sudeste contribuía com $59,40 \%$ do PIB; Sul, com 17,09\%; Nordeste, com 13,83\%; Centro-Oeste, com 5,33\%; e Norte, com 4,35\%. 
Já de uma estimativa referente a 1992 depreende-se que a região Sudeste passa a contribuir com 56,18\% do PIB; Sul, com 16,74\%; Nordeste, com 15,86\%; Centro-Oeste, com 5,69\%; e Norte, com 5,53\% (tabela 1). Verifica-se, assim, que a participação das regióes Nordeste e Norte aumentou proporcionalmente às regiōes Sudeste e Sul. Como ver-se-á, entretanto, isso não implica diminuição nas disparidades sociais, sejam quais forem os indicadores utilizados.

Quanto ao perfil etário da população, a partir da década de 70 evidencia-se uma tendência de envelhecimento (4,9\% da população, ou mais de 10 milhốes de brasileiros, têm 65 ou mais anos de idade); por outro lado, os mesmos dados revelam que $34,7 \%$ dos brasileiros têm até 14 anos de idade, o que significa um contingente de aproximadamente 70 milhôes de pessoas (tabela 2).

Mais da metade da população brasileira declara-se branca $(55,3 \%), 4,9 \%$ preta, $39,3 \%$ parda e $0,5 \%$ amarela. Dados relativos ao analfabetismo no país demonstram acesso diferenciado à educação segundo a cor: enquanto $12,1 \%$ dos brancos são analfabetos, entre os pretos a proporção é de $30,1 \%$, e entre os pardos, de $29,3 \%$ (tabela 3 ).

Dois outros indicadores, extremamente sensíveis às condições de vida da população, auxiliam a dimensionar as disparidades sociais brasileiras: a esperança de vida ao nascer e a taxa de mortalidade infantil. Para o ano de 1990, a esperança de vida média do brasileiro ao nascer era de 65,49 anos. Isso significa um ganho, na última década, de 3,51 anos, pois em 1980, a esperança de vida média no Brasil era de 61,98 anos (com as mulheres superando os homens, em média, por 6,84 anos). Também com relação a esse indicador observa-se acentuada diferenciação segundo as regióes: enquanto na região Nordeste a esperança de vida ao nascer é de 64,22 anos, na regiáo Sul é de 68,68 , seguida de perto pela região Sudeste, com 67,53 anos (tabela 4).

Com relação à esperança de vida, contudo, mais grave do que as disparidades regionais é a disparidade por renda. Cálculos realizados a partir de dados de 1984 demonstram que, para o grupo que ganhava até um salário mínimo, a esperança de vida ao nascer era de 57,5 anos, enquanto para o grupo dos que ganhavam mais de cinco salários mínimos elevava-se a 73,4 anos. Associando-se rendimento mensal e distribuição regional observa-se, a partir desses mesmos dados, confrontando-se a média obtida para o grupo mais pobre da região Nordeste $(51,5$ anos) com a do grupo mais rico da regiáo Sudeste ( 75 anos), que o diferencial de esperança de vida equivaleria a 23,5 anos (tabela 5).

No que se refere à taxa de mortalidade infantil, indicador tradicionalmente considerado dos mais sensíveis para traduzir a estreita relação entre condições de vida e saúde da população, as mesmas disparidades se fazem presentes. 
Embora para o conjunto da população essa taxa tenha decrescido de maneira acentuada no decorrer da década de 80 - passando de 65,8 por mil nascidos vivos, em 1980, para 51,6 em 1990 - verifica-se que, se para a região Sul ela é de 26,7 por mil, na região Nordeste é de 88,2 por mil. Para a região Norte, essa taxa é de 53,2 por mil, para a Centro-Oeste é de 33 por mil, e para a Sudeste de 30 por mil (tabela 6 ).

Associando-se novamente disparidades regionais e sócio-econômicas, constata-se que, enquanto para o ano de 1989 a taxa de mortalidade infantil variava de 33 por mil nascidos vivos na regiáo Sudeste a 75 por mil nascidos vivos na região Nordeste, sua incidência em termos de renda apresentava a seguinte variação: entre famílias com renda de até um salário mínimo era de 75,2 por mil nascidos vivos, ao passo que entre famílias com renda superior a um salário mínimo correspondia a 33,3 por mil nascidos vivos.

No que diz respeito aos serviços de saneamento básico, a década de $\mathbf{8 0}$ experimentou expansão significativa. Em 1990, 63,5\% da população brasileira tinha acesso ao abastecimento de água no interior do próprio domicílio, $37,2 \%$ possura instalaçóes sanitárias ligadas à rede geral e $61 \%$ tinha serviço de coleta de lixo. Não obstante, a distribuiçáo desses serviços era acentuadamente desigual entre áreas urbanas e rurais. No caso do acesso ao abastecimento de água no interior do próprio domicílio, enquanto no meio urbano a cobertura era de $81,6 \%$, no meio rural era de somente $12 \%$; com relação às instalaçōes sanitárias ligadas à rede geral, a disparidade era de $48,5 \%$ no meio urbano, para $5 \%$ no meio rural; finalmente, no que diz respeito ao serviço de coleta de lixo, essa disparidade correspondia a $78,5 \%$ no meio urbano para $11,3 \%$ no meio rural (tabela 7 e gráfico 1 ).

Esses dados ganham importância pelo impacto do acesso a serviços de saneamento básico sobre a mortalidade infantil. Entre as famílias com renda per capita mensal de até meio salário mínimo, a taxa de mortalidade infantil em famílias que dispunham de infra-estrutura familiar adequada, em termos de rede geral de água e de esgoto ou fossa séptica, era de 51,6 por mil nascidos vivos; no segundo caso, das famílias sem acesso a essa infra-estrutura, a taxa elevava-se para 107,9 por mil nascidos vivos.

Tal como nos demais indicadores, aqui também a extensão da cobertura corresponde a disparidades regionais e por renda. No caso do escoamento sanitário, por exemplo, somente a região Sudeste ultrapassou o nível de $50 \%$ de atendimento; nas demais regiốes, essa proporção varia de um mínimo de $9,4 \%$ (Nordeste) a 36,5\% (Centro-Oeste). Quanto à distribuição do acesso por nível de renda, ela varia de $33,7 \%$ na classe de rendimento domiciliar de até um salário mínimo a $90 \%$ nos casos de mais de dez salários mínimos. 
Do ponto de vista do quadro sanitário, essa realidade social traduz-se no que se vem denominando de transiz̧ão epidemiológica: a convivência de doenças infantis e infecto-contagiosas com doenças crônicas e degenerativas, às quais se somam as mortes por causas externas. Hoje, a principal causa de mortalidade no país são as doenças do aparelho circulatório, seguidas das neoplasias, das doenças do aparelho respiratório, das causas externas (excluídos homicídios e suicídios), das doenças do aparelho digestivo e das complicaçóes na gravidez e no parto.

Embora a ordem de incidência dessas causas de mortalidade varie regionalmente, o peso da variável renda é decisivo. Onde a pobreza está mais presente, é maior a mortalidade por enfermidades típicas dessa situação social (como as doenças infecto-parasitárias) e vice-versa. O fato é que, no país, convivem, hoje, doenças típicas da pobreza e da riqueza. Isso significa que, para atender a esse quadro sanitário, não bastam medidas tipicamente preventivas, de caráter coletivo, fazendo-se também necessárias ações de atenção médica de alta complexidade tecnológica.

Também a distribuição regional dos equipamentos de saúde é altamente desigual, tanto em termos gerais como em termos da relação público-privado (para o ano de 1990, 66,8\% dos equipamentos de saúde cram públicos e 33,2\% privados): $7,4 \%$ dos mesmos localizam-se na região Norte; $30,1 \%$ na região Nordeste; $36,3 \%$ na Sudeste; $20,1 \%$ na Sul; e 6,1\% na Centro-Oeste. Embora essa distribuição corresponda, em certa medida, à densidade populacional das distintas regiôes, em termos da composição público-privado, parece estar vinculada à distribuição regional da renda. Assim, enquanto na região Norte $83,2 \%$ dos estabelecimentos de saúde são públicos e somente $3,8 \%$ privados, na região Sudeste apenas $59,9 \%$ dos estabelecimentos são públicos, nela se localizando nada menos que $43,6 \%$ do total dos estabelecimentos privados. Na regiāo Nordeste, os percentuais são respectivamente $74,6 \%$ e $23,1 \%$; na Sul, $63,0 \%$ e 22,3\%; e na Centro-Oeste $61,5 \%$ e $7,1 \%$. A precoce e acentuada privatização dos serviços de saúde no país (cerca de $75 \%$ dos leitos hospitalares são privados), associada a um modelo de saúde pública centrado no atendimento hospitalar, adiciona complexidade à questão da saúde no Brasil.

No que tange à educação, embora diversos indicadores apontem para uma melhora do nível de educação formal da população brasileira durante a década de 80 , a existência de 20,2 milhóes de analfabetos com dez ou mais anos de idade representa enorme desafio. Desafio tanto maior dada a acentuada variação das taxas de analfabetismo, quer em termos regionais quer em termos de níveis diferenciais de renda. Enquanto no Sudeste a taxa de analfabetismo das pessoas de dez anos ou mais é de $10,9 \%$, a da região Nordeste é três vezes maior, atingindo $35,9 \%$. No caso dos níveis diferenciais de renda, a desigualdade é ainda mais acentuada: entre os jovens de dez a 14 anos com renda 
familiar per capita de mais de dois salários mínimos, é praticamente residual a chance de serem analfabetos $(2,6 \%)$; essa probabilidade, entretanto, torna-se 14 vezes mais alta no caso dos jovens com renda familiar per capita de até meio salário mínimo.

Além disso, dados estatísticos mostram uma curva decrescente na velocidade com que se vem logrando eliminar o analfabetismo no país, apesar da curva decrescente da taxa de crescimento populacional. Para a década de 60, o declínio percentual da taxa de analfabetismo foi de $-7,3$ (depois de um declínio na década de 50 de $-12,3$ ); para a década de 70 foi de $-6,6$; e para a década de 80 , de apenas -5 (gráfico 2).

Por fim, dois indicadores que dizem respeito ao mundo do trabalho e que apontam, uma vez mais, para a complexidade do fenômeno das desigualdades sociais no Brasil: um deles diz respeito ao percentual de crianças entre dez e 14 anos que trabalham, as quais, em tese, deveriam estar freqüentando a escola; $o$ outro refere-se ao rendimento proveniente do trabalho.

No Brasil, 16,9\% das crianças entre dez e 14 anos já trabalham. Neste caso, as disparidades regionais são bem menores se comparadas com os indicadores anteriores. Nordeste e Sul apresentam percentuais bastante próximos $-21,8 \% \mathrm{e}$ $20,5 \%$ respectivamente - apesar de, na região Sul, os indicadores sociais apontarem para condiçóes de vida bastante mais elevadas. O mesmo raciocínio vale para a regiáo Sudeste, com um percentual de $12,2 \%$ quando comparada com as regiôes Centro-Oeste $(17,8 \%)$ e Norte $(10,7 \%)$. Essa menor discrepância entre os percentuais regionais pode estar indicando o papel do trabalho infantil como estratégia de composiçâo da renda mensal familiar em nível nacional. Vale considerar que, na região Nordeste, em $\mathbf{5 3 , 7 \%}$ dos casos o rendimento familiar per capita é de até meio salário mínimo, enquanto na região Sul esse percentual é de $21,8 \%$ e na região Sudeste, de $16,5 \%$.

É na região Nordeste que se concentra o maior percentual de pessoas da população ocupada que trabalham $\mathbf{4 0}$ ou mais horas semanais, com rendimento inferior a um salário mínimo: $25 \%$ da população economicamente ocupada (PEO). Para as demais regióes, a queda desse percentual é bastante significativa: 10,8\% da $\mathrm{PEO}$ na região Centro-Oeste, $8,8 \%$ na regiáo Sul, $8,6 \%$ na região Norte e $8,2 \%$ na região Sudeste.

Os dados até aqui apresentados visam a traçar um panorama das desigualdades sociais e regionais no Brasil. Entretanto, para além da complexidade do fenômeno, derivada de situações altamente heterogêneas, a magnitude das questões sociais a serem enfrentadas vem sendo agravada pelo processo de crescente concentração de renda dos últimos 30 anos (tabela 8). 
Enquanto na década de 60 a renda apropriada pelos $10 \%$ mais ricos da população era 34 vezes superior à renda apropriada pelos $10 \%$ mais pobres, em 1990 essa proporção se eleva para 78 vezes, ao mesmo tempo em que a rendaper capita é inferior àquela registrada em 1980 (US\$2884,5 e US\$2999,7 respectivamente). A isso soma-se o fato de que, diversamente da década de 60 , quando $o$ setor mais penalizado pela crise econômica foi a classe média, nos anos 80 , o setor mais atingido foi aquele localizado na cauda inferior da distribuição. Como resultado, o perfil da distribuição de renda no Brasil tem o seguinte formato básico: enquanto os $10 \%$ mais ricos apropriam-se de quase metade da renda total $(48,1 \%)$ - e os $1 \%$ mais ricos de $13,9 \%$ do total de rendimentos -, aos $10 \%$ mais pobres cabem apenas $0,8 \%$ do total de rendimentos - e aos $50 \%$ mais pobres, $12,1 \%$ (tabelas 9 e 10; gráfico 3).

Essa consideração preliminar de alguns indicadores, com alto grau de agregação, revela uma situação marcada por amplos contrastes e tendências contraditórias. O padrão de crescimento econômico que prevaleceu no país desde os anos 30 e a crise de seu esgotamento, que marcou os últimos quinze anos da sociedade brasileira, deixaram como herança, por um lado, uma sociedade urbano-industrial moderna e complexa e, por outro, um dramático quadro social, marcado por profundas desigualdades.

O balanço da década de 80 revela melhorias em determinados setores, tais como a redução da taxa da analfabetismo e o aumento do grau de escolaridade formal da população; a erradicação da poliomielite; a ampliação do número de domicílios dotados de infra-estrutura adequada de água e esgoto; e a redução das taxas de mortalidade infantil. Há numerosos indícios, porém, de que se teria acentuado o contraste entre ricos e pobres, multiplicando-se, ao mesmo tempo, os sinais de exclusão social.

As mudanças em profundidade que vêm ocorrendo nos planos científicotecnológico, financeiro, organizacional e industrial exigem e, ao mesmo tempo, permitem uma redefinição profunda do modelo de desenvolvimento do país, no sentido de buscar uma estrutura produtiva mais competitiva, mais aberta e mais integrada ao resto do mundo. Essas mudanças, como se sabe, podem agravar antigas desigualdades e criar novas vulnerabilidades, afetando de forma negativa regiốes e grupos sociais. O desafio que se impóe, portanto, é o de buscar um modelo de desenvolvimento que permita a conciliação do imperativo de modernização da economia com a redução das disparidades regionais e sociais.

Nota: desenvolvimento social e eqüidade

O tema do desenvolvimento social é suficientemente amplo para gerar 
consensos quanto à sua prioridade $e$, simultaneamente, comportar profundas discrepâncias quanto às concepçóes e estratégias para sua promoção.

Tratar o tema do desenvolvimento social requer, antes de mais nada, enfrentar a questão das iniqüidades sociais de toda ordem - gênero, raça, renda, emprego, acesso universal a bens de consumo coletivo, dentre outros - que marcam nossa sociedade, sem restringi-las à dimensão única da pobreza.

Tal abordagem apresenta, de imediato, várias implicações. Em primeiro lugar, exige a superação da dicotomia entre desenvolvimento econômico e desenvolvimento social; em conseqüência, a busca de uma nova articulação entre políticas econômicas e políticas sociais que visem à efetiva redistribuição de renda, forjando-se, assim, modelo de desenvolvimento capaz de promover maior justiça social.

Um enfoque articulador das dimensóes econômicas e sociais do processo de desenvolvimento requer nova superação, desta vez de concepção e desenho de políticas sociais tendo como alvo exclusivo os despossuídos (carentes), o que significa atribuir-lhes o estatuto de meras políticas compensatórias das desigualdades sociais; ao contrário, essa nova concepção implica conceber políticas sociais, também elas, como promotoras de desenvolvimento econômico, emprego e trabalho.

Em suma, a questão do desenvolvimento com eqüidade demanda que se concebam as políticas econômicas como parte do processo de desenvolvimento social, e que, por sua vez, as políticas sociais, ao definirem seu público alvo, concebam os grupos mais vulneráveis - os pobres - como sujeitos e não meramente como objeto de sua intervenção.

No caso específico das políticas sociais, implicaria não mais concebê-las e desenhá-las a partir do marco da oposiçâo básica entre universalização e focalização - o qual teria como base definidora a necessidade -, mas sim pela lógica do direito. A dicotomia universalização/focalização constitui, na verdade, um falso dilema já que a opção por políticas sociais universalistas, que respondam aos direitos dos cidadãos, não exclui quando necessário a possibilidade de políticas focalizadas.

Trata-se, portanto, de trazer para o eixo central da formulação de projetos de desenvolvimento a questão da cidadania, reformulando-se as relaçóes entre Estado e sociedade, democratizando-se as distintas formas de gestão e criando-se novos espaços públicos. Para além disso, trata-se da construção democrática de um projeto para a sociedade pautado pela busca de maior eqüidade e integraçáo sociais, o qual, ao mesmo tempo em que reafirme a identidade nacional no con- 
texto da globalização, preserve o direito às diferenças, sem que estas se traduzam em exclusão e discriminação sociais.

Nesse contexto, atividades de coleta, sistematização, análise e divulgação dos dados sócio-econômicos acerca da realidade brasileira assumem caráter fundamental. Ocorre que as informaçóes hoje disponíveis estão defasadas em três a quatro anos, são díspares e de difícil compatibilizaçăo entre si. E se isso é fruto da perda relativa de importância dos organismos responsáveis por aquelas atividades no período mais recente, em que se assistiu a uma inflexão das prioridades na direção de responder a necessidades básicas definidas pela lógica do desenvolvimento, recuperá-los torna-se condição básica para imprimir maior eficiência e eficácia, não só às políticas públicas - ao Estado, enfim - mas também ao exercício da cidadania. A disponibilidade e o acesso à informação constituem requisitos essenciais para um processo de desenvolvimento com eqüidade.

A circunstância de que o desenvolvimento social, assim entendido, não se reduz ao alívio imediato da pobreza, ou a uma orientação exclusiva para os grupos socialmente mais vulneráveis, tampouco autoriza que, de maneira simplista, se contraponha o mercado ao Estado e este à sociedade, ou ainda a política econômica à política social. Ao mesmo tempo, não cabe ignorar que o próprio mercado de trabalho pode atuar como elemento estruturador das desigualdades e da exclusão social.

Nesse sentido, a experiência brasileira dos anos recentes, no que diz respeito às distintas práticas de construção da cidadania, representa uma contribuiçáo inovadora em pelo menos três aspectos: incorpora a dimensão política ao conceito de desenvolvimento social, até então relegado aos estreitos limites de dimensão residual em relação ao econômico; coloca em evidência que o social não deve subordinar-se ao econômico, mas que ambos devem estar estreitamente articulados entre si; e contribui para fundamentar a crítica à redução das noções de cidadania e participação social a meros mecanismos compensatórios, face à exclusão gerada pelo mercado.

Em suma, a experiência brasileira do período recente redimensiona a cidadania e a participação social como fatores propulsores de transformação na agenda do desenvolvimento, e não mais como simples elementos compensatórios das forças desestruturadoras do mercado. Essa mesma experiência mostra que o processo de mudança de um padrão de desenvolvimento excludente para outro que inclua e integre os cidadãos, no sentido de prover suas necessidades básicas e aspirações humanas, é necessariamente lento, penoso e conflituoso, sobretudo num contexto caracterizado pela permanência de desigualdades e pela tradição centralizadora e autoritária do Estado. 
Em decorrência, há que se ter clara a distinção - e suas implicações entre desenvolvimento social em termos de alívio da pobreza e em termos da superação da pobreza. No primeiro caso, o que está em jogo são políticas de caráter mais imediato, assistencialista, e, na sua grande maioria, focalizadas sobre os grupos mais vulneráveis. Em outras palavras, políticas que tendem a assumir a forma de programas emergenciais. Já no segundo caso - o da superação da pobreza - trata-se de políticas, já num primeiro momento, embora com horizonte de médio e longo prazos, balizadas pela construção de um novo modelo de desenvolvimento sustentado, que priorize o crescimento econômico com eqüidade social e no qual as políticas econômicas assumam também a dimensão de políticas sociais.

\section{A pobreza no Brasil}

Embora os dados utilizados para mensuração da pobreza no Brasil difiram segundo as diferentes instituiçōes e fontes de informação, essas divergências não comprometem o consenso acerca da magnitude do fenômeno. Estudo do Banco Mundial referente a 1989 , por exemplo, aponta que $40,9 \%$ da população brasileira vivia em situação de pobreza, definida esta como a disponibilidade de renda per capita mensal inferior a US\$60. O mesmo estudo demonstra que os brasileiros que, à época, se situavam entre os $20 \%$ da base da pirâmide de distribuição de renda detinham somente $2,1 \%$ da renda total. Esses dados, quando comparados à média para a América Latina e Caribe, permitem situar a gravidade da questão da pobreza no Brasil: para aquele mesmo ano de $1989,31,5 \%$ da população latinoamericana e caribenha viviam em situação de pobreza absoluta, detendo os $20 \%$ da base da pirâmide distributiva, em média, $4,1 \%$ da renda total. Já para o ano de 1990, pesquisas sobre a pobreza e desigualdade no Brasil estimam em torno de $27 \%$ a população de pobres no país, o que significa cerca de 39 milhôes de brasileiros (tabela 11). Em suma, quaisquer que sejam os dados utilizados, constata-se que aproximadamente um terço dos brasileiros estão vivendo em si-tuaçóes de pobreza.

Partindo-se desses dados, fruto de pesquisa nacional por amostra domiciliar (Pnad, 1990), e utilizando-se uma classificação que divide a população entre pobres (aqueles cuja renda, inferior à linha de pobreza, não permite atender suas necessidades básicas de alimentação, moradia, vestuário etc.), indigentes (aqueles cuja renda não permite atender nem mesmo às necessidades básicas alimentares) e não-pobres (aqueles cuja renda se situa acima da linha de pobreza), foi possível sistematizar algumas das principais características da pobreza no Brasil.

- a pobreza apresenta um forte componente regional: atinge proporções mais elevadas nas regiōes Norte e Nordeste do país, reduzindo-se em direção ao Sul. Seja em Recife, por exemplo, capital de um importante estado nordestino, ou nas 
áreas rurais do Nordeste, a proporção de pobres corresponde a quase $50 \%$ da população. Mais ainda, ao se caracterizar como pobres aqueles que apresentam renda familiar per capita igual ou inferior a um quarto do salário mínimo (US\$ 35 mensais, valor de 1990), constata-se que, na área rural do Nordeste, encontram-se $63 \%$ da pobreza rural brasileira e $32 \%$ do total de pobres do país.

- a incidência da pobreza é sensivelmente mais elevada nas áreas rurais, embora nas regióes mais urbanizadas do país a pobreza passe a ser um fenômeno preponderantemente metropolitano (tabela 11).

- em termos de volume, e tomado o pais em seu conjunto, mais de dois terços dos pobres são pobres urbanos (metropolitanos ou não metropolitanos), o que se explicaria em função do acelerado processo de urbanização das décadas mais recentes (gráfico 4).

Quanto aos indigentes, estes representam $12 \%$ da população brasileira, o que significa 16,6 milhões de pessoas. As características dessa forma mais acentuada de pobreza são semelhantes àquelas relativas à pobreza em geral:

- forte componente regional: $55 \%$ deles são encontrados na região Nordeste.

- incidência flagrantemente mais elevada no meio rural: $22,7 \%$ da população, contra $9,4 \%$ na área urbana e $8 \%$ na metropolitana. Já no caso das regiốes mais urbanizadas do país, ao contrário do que ocorre com o fenômeno da pobreza, a indigência demonstra não ser um fenômeno preponderantemente metropolitano, mas sim urbano-metropolitano. Para o país como um todo, os indigentes rurais representam $42,6 \%$ do conjunto.

De qualquer ângulo que se olhe, porém, os números absolutos são expressivos. No caso do Brasil, promover uma política de desenvolvimento social significa retirar da situação de pobreza e de indigência contingentes de 42 milhões e 16 milhões de pessoas, respectivamente.

Quando se comparam os indicadores de 1990 com os do início da década anterior - 1981 -, verifica-se que a magnitude da pobreza e da indigência não aumentou no decorrer desse período; o que ocorreu foi um aumento da taxa de desigualdade na sociedade como um todo, agravado pela recessão econômica e pelo acelerado processo de urbanização. Fortes descontinuidades na condução da política econômica - quatro choques heterodoxos entre 1986 e 1990 -, redução dos níveis de investimento e bruscas oscilações nas taxas de inflação fizeram com que, ao longo da década, o PIB real evoluísse a uma taxa anual de apenas $1,5 \% \mathrm{e}$ o PIB per capita declinasse de US\$3,000 para US\$2,856 (apesar de uma queda de $1,9 \%$ na taxa de crescimento populacional), contribuindo decisivamente para 
o agravamento das desigualdade de renda (os $10 \%$ mais ricos passam a se apropriar de quase a metade do total de rendimentos).

Do ponto de vista da incidência, constatou-se que a pobreza e, em particular, a indigência ainda são fenômenos predominantemente rurais e regionais (particularmente expressivos no Nordeste, onde compóem um dos traços característicos vinculados ao padrão de ocupação produtiva e de desenvolvimento sócioeconômico na área rural). No meio urbano, entretanto, o rompimento dos laços tradicionais de solidariedade e dependência, associado a contrastes extremos de riqueza e poder, faz com que situaçôes de pobreza e indigência tornem-se fonte de tensões sociais. Uma das manifestaçôes mais agudas desse fenômeno reside no aumento da violência urbana, em particular nas principais metrópoles do país.

São já por demais conhecidos os atributos que determinam uma situação de pobreza. Dentre eles destacam-se: baixo nível educacional (que somente possibilita o acesso a postos de trabalho de baixa produtividade e remuneração, os quais exigem pouca ou nenhuma qualificação); características do chefe de família (famílias chefiadas por mulheres são particularmente vulneráveis à pobreza, $o$ mesmo ocorrendo quando os chefes são pardos ou pretos, para não falar do fator idade, diante da alta seletividade do mercado de trabalho a favor dos mais jovens); tamanho e estrutura da família (famílias numerosas, com crianças menores de dez anos de idade); e local de residência (rural/urbano e regional) (tabelas 12 e 13).

Análises recentes mostram que a probabilidade de um brasileiro șer pobre quando reúne o lado adverso dessas características (mulheres, negras, com baixo nível educacional, chefes de família, com grande número de crianças menores de dez anos, vivendo no Nordeste) é de $95 \%$. Demonstram, ainda, que essa probabilidade se reduz para $87 \%$ se a família não residir na região Nordeste. Evidenciam, por outro lado, se o chefe de família tiver escolaridade superior a quatro anos, que essa probabilidade se reduz para $86 \%$, a despeito de os demais aspectos serem negativos, significando ser o nível educacional do chefe de família a característica mais fortemente associada à pobreza.

A pobreza metropolitana. $\mathrm{O}$ acelerado processo de urbanização das últimas décadas trouxe consigo o fenômeno da metropolização da pobreza, a qual passa a fazer parte do cotidiano da sociedade brasileira. A distribuição da pobreza metropolitana acompanha o padrão regional da pobreza, ou seja, em termos de proporção da população total, situações de pobreza são mais presentes nas metrópoles das regióes Norte e Nordeste. Em termos absolutos, contudo, mais de $\mathbf{5 0 \%}$ dos pobres metropolitanos concentram-se nas metrópoles da região Sudeste: Rio de Janeiro e São Paulo, especialmente em suas áreas periféricas. Reproduz-se, assim, nas metrópoles, o processo de exclusão social, cujas distintas formas de manifes- 
tação e diferentes graus de complexidade desafiam o poder público e a própria sociedade a encontrarem formas adequadas de enfrentá-lo.

Tomando-se como exemplo a cidade de São Paulo, segunda maior metrópole da América Latina, bastam alguns dados para ilustrar a magnitude das disparidades sociais que marcam essas gigantescas concentraçốes humanas. Uma criança nascida em família residente na periferia da cidade tem 3,35 vezes mais chances de morrer antes de atingir um ano de idade do que uma criança nascida no seio de família residente nas áreas centrais da cidade. Quanto à educação, se compararmos uma área periférica a outra central, os dados indicam que, no primeiro caso, o número de chefes de família com menos de um ano de escolarização é mais de 22 vezes superior que no segundo. Quanto à renda do chefe de família, a proporção daqueles que recebem o equivalente a 1,5 salários mínimos (preço médio da cesta básica) em uma área da periferia é seis vezes maior do que na área central.

É importante salientar que os dados anteriormente mencionados, dentre os quais mais expressivo é o que se refere à mortalidade infantil, apontam para o fato de ser a situação de pobreza, enquanto insuficiência de renda, agravada quando ocorre simultaneamente à carência de acesso a bens e serviços básicos. Dessa forma, quando se trata de caracterizar a pobreza com o objetivo de implementar medidas para seu alívio e superação, a utilização da renda como indicador único revela-se insuficiente. Há que se ter em conta os elevados déficits de infra-estrutura social, cuja oferta é essencial para garantir condiçóes mínimas de vida, particularmente em ambientes de alta densidade de ocupação. Faz-se, portanto, necessário associar à caracterização da pobreza e da indigência variáveis relativas à satisfação ou insatisfação de necessidades básicas, que não se limitam à dimensão da renda.

Se o indicador renda fosse suficiente para caracterizar uma situação de pobreza, o valor necessário para a eliminação da pobreza metropolitana, por exemplo, que, no ano de 1990 , compreendia $29 \%$ dos pobres e $20,6 \%$ dos indigentes, seria equivalente a apenas $3,7 \%$ da renda dos não-pobres, montante de recursos necessário para garantir àquele contingente a satisfação de suas necessidades básicas, no âmbito do consumo privado. Essa medida, no entanto, ademais de politicamente insustentável, revelar-se-ia inteiramente insuficiente para retirar os pobres da sua condição.

\section{Tipos de pobreza e acesso a programas sociais}

A utilização simultânea da definição de linhas de indigência e pobreza por níveis de renda com um indicador da satisfação de necessidades básicas possibilita caracterizar quatro tipos de pobreza. 
- pobreza estrutural: quando as famílias se encontram abaixo da linha de pobreza e têm suas necessidades básicas insatisfeitas (atinge 12\% dos domicílios urbanos);

- pobreza mais recente: quando as famílias se encontram abaixo da linha de pobreza, mas mantêm necessidades básicas satisfeitas (atinge pelo menos $21 \%$ do total dos domicílios urbanos);

- pobreza por necessidades básicas insatisfeitas: quando as famílias, embora situando-se acima da linha de pobreza, não conseguem ter suas necessidades básicas satisfeitas (atinge aproximadamente $6 \%$ do total dos domicílios urbanos);

- não-pobres "stricto sensu": famílias acima da linha de pobreza e com necessidades básicas satisfeitas (atinge aproximadamente $60 \%$ do total dos domicílios urbanos).

A partir da combinação dessas variáveis, pode-se traçar o seguinte quadro das dimensões da questão da pobreza no Brasil, calculada em nível de domicílios (dados relativos a 1989, tabelas 14,15 e 16 ):

- há mais de 8,6 milhões de domicílios urbanos pobres no país; 2,8 milhões, no nível de indigência;

- há cerca de 3,2 milhôes de domicílios rurais pobres;

- um em cada três domicílios urbanos é pobre; na área rural, essa proporção chega a quase um em dois;

- $18,9 \%$ dos domicílios urbanos (mais de 4,8 milhóes de domicílios) encontram-se em situação de pobreza estrutural (famílias pobres, indigentes ou não, que têm suas necessidades básicas insatisfeitas). Este segmento, por ser menos vulnerável às oscilações da conjuntura econômica, demandaria medidas mais a médio e longo prazos, igualmente estruturais, para ter superada a sua condição de pobreza;

- dentre as crianças da área urbana entre zero e três anos, cerca de metade são pobres. Reproduz-se, também aqui, a extrema desigualdade na distribuição da pobreza pelas várias regiôes do Brasil: enquanto $40 \%$ das crianças da região Nordeste são indigentes, e duas em cada três são pobres (indigentes ou não), na região Sul $12 \%$ das crianças são indigentes, e um em cada três é pobre (indigente ou não).

O mesmo tipo de procedimento permite compor o seguinte quadro relativo à indigência no Brasil (tabelas 17 e 18): 
- o número total de domićlios em nível de indigência (urbanos e rurais) é de 24,7 milhões;

- cerca de $\mathbf{4 5 \%}$ dos indigentes estáo na área rural; outros $40 \%$ localizam-se em áreas urbanas não metropolitanas; e os 15\% restantes, nas áreas metropolitanas;

- também neste caso, a desigualdade regional se faz presente: a grande maioria dos indigentes encontra-se no Nordeste do país $(\mathbf{5 8 , 8 \%}$ do total de pessoas sobrevivendo nessa condição, o que significa 14,6 milhões de brasileiros). Já nas áreas urbanas da região Sudeste, localizam-se 16,9\% dos indigentes. Esses dados ganham ainda maior significado pelo fato de a região Nordeste abrigar apenas $30 \%$ da população brasileira, enquanto a Sudeste compreende $40 \%$ da população total.

Mas se já existe uma dramática diferença de grau entre a situação de pobreza e a de indigência no que diz respeito a condições de habitação, encargos familiares, base educacional, precariedade de vínculos empregatícios e condições de trabalho, e número de pessoas empregadas, as diferenças regionais voltam, ainda uma vez, a se fazerem sentir de modo marcante.

Comparando-se a situação dos domicilios indigentes do Nordeste com os do Sudeste, tem-se que:

- enquanto no Nordeste mais de $64 \%$ desses domićlios apresentam condiçóes sanitárias precárias, no Sudeste esse percentual é de 31\%;

- no Nordeste, cada domicílio possui, em média, 2,1 crianças com menos de dez anos de idade, enquanto no Sudeste a média é de 1,5;

- a proporção de chefes de famullia analfabetos no Nordeste é de 59\%; na regiáo Sudeste, de $34 \%$;

- em 19\% dos domicillios do Nordeste nenhum membro está ocupado, sendo que na região Sudeste esse percentual cai para $10 \%$;

- nos domicílios nordestinos há 1,8 pessoas em idade inativa para cada pessoa em idade ativa; na regiāo Sudeste essa média é de 1,4.

Esses dados, ao traçarem um retrato da pobreza no Brasil, indicam enorme heterogeneidade de situações, não só em termos de condiçóes materiais de vida, mas também de estratégias de sobrevivência e de redes de sociabilidade e solidariedade. 
É exatamente pelo fato de os programas sociais no Brasil não levarem em conta essa heterogeneidade, sem mencionar a tradição centralizadora e clientelista do Estado, que, pela sua baixa eficácia e efetividade, acabam por reproduzir, quando não agravar, as disparidades sociais. Estudo do Banco Mundial sobre o gasto público em programas sociais no Brasil demonstra, a partir de dados de 1988, que o quinto mais pobre da população recebia apenas $7 \%$ do total dos benefícios sociais, enquanto, no outro extremo, os $4 \%$ mais ricos recebiam aproximadamente $18 \%$ do mesmo total.

Programas de atendimento a gestantes e nutrizes são contundentes exemplos desse mal. Enquanto o programa de atenção pré-natal apresentava uma cobertura de $29,6 \%$, e o programa de suplementação alimentar cobria $20,3 \%$ das gestantes em situação de indigência das regióes Norte, Nordeste e CentroOeste, esses percentuais para as regiōes Sul e Sudeste eram de $51 \%$ e $20,3 \%$ respectivamente. Tais dados sugerem duas coisas: em primeiro lugar, que programas nutricionais e de suplementação alimentar apresentam maiores graus de focalização nos estratos e nas regióes mais pobres. Em segundo lugar, que programas de atenção pré-natal, que pressupõem maior disponibilidade de equipamentos de saúde, maior acesso à atenção médica $\mathrm{c}$ a informações, tendem a ser mais seletivos, cobrindo menos as pessoas e regiōes mais pobres.

Quanto aos programas de distribuição gratuita de alimentos para crianças de zero a sete anos, no geral atingem em menor grau os mais pobres dentre os pobres: $12,7 \%$ dos indigentes, $20,3 \%$ dos pobres não-indigentes, $20,1 \%$ dos pobres recentes e $14,3 \%$ dos pobres estruturais. Além da baixa cobertura ( 12 a $20 \%$ das crianças), os dados revelam que esses programas assumem caráter emergencial para o caso dos pobres recentes, embora, neste caso, atinjam também um grupo relativamente menos necessitado.

Mas é exatamente na circunstância de grande parte desses programas supor presença de (e acesso a) equipamentos públicos que se encontra uma das explicaçóes possíveis para a disparidade do acesso à escola com merenda escolar para crianças indigentes entre sete e 14 anos: enquanto nas regióes Sul e Sudeste ela é de $76 \%$, nas demais regióes do país é de apenas $43 \%$. Também neste caso, as crianças não-pobres recebem cobertura semelhante à das crianças indigentes: $40 \%$ delas recebem merenda escolar.

Ainda no que diz respeito a crianças, agora da faixa etária de zero a seis anos, os programas de creche e escolas maternais também apresentam baixa cobertura: dentre os pobres, indigentes ou não, as matrículas cobrem $11,7 \%$, enquanto para os não pobres a cobertura é de $24,3 \%$. Isso indica, uma vez mais, que a baixa efetividade desses programas e políticas penaliza mais fortemente os grupos mais desfavorecidos. 
Tomando-se agora o outro extremo - a faixa etária de 60 ou mais anos -, verifica-se que $o$ acesso a pensóes e aposentadorias do sistema público de seguridade social é de $65 \%$ e $70 \%$ nos níveis de indigência e pobreza, respectivamente, embora distribuído diferentemente entre as áreas urbana e rural. Isso significa que $31 \%$ dos idosos não recebem qualquer tipo de auxílio da seguridade social, o que corresponde a um total de 3,1 milhões de pessoas, dentre as quais mais de meio milhão são pobres em nível de indigência e quase $800 \mathrm{mil}$ são pobres não-indigentes. Dentre esses pobres, indigentes ou não, mais de 700 mil não trabalham, e com grande probabilidade não dispõem de qualquer fonte de rendimento para sua sobrevivência.

Fome e desnutrição infantil. Com vistas à formulação de um programa de segurança alimentar, foi elaborado um estudo que desenha o mapa da fome no Brasil. Embora exista controvérsia quanto à magnitude do problema, o documento indica que 31.679.096 brasileiros (ou nove milhôes de famílias) defrontam-se com o problema da fome. A distribuição do problema também obedece ao padrão regional que vem sendo assinalado: 17,2 milhôes dos atingidos localizam-se no Nordeste e 7,9 milhões na região Sudeste. É no Nordeste rural que se concentram $63 \%$ dos indigentes que vivem nessas condições, ao passo que outros $30 \%$ vivem nas áreas metropolitanas e urbanas. Isso explica o fato de a região Sudeste apresentar a segunda maior concentração de indigentes: nela localizamse as maiores metrópoles do país, apesar de o fenômeno da fome urbana disseminar-se por todo o território nacional.

Já outro estudo sobre o retardo do crescimento na infância - uma vez que o padrão normal ocorre na presença de um adequado estado nutricional e na ausência de enfermidades freqüientes (com todas as pré-condiçóes que isso implica) - verifica, a partir de dados de 1989 , que $15,9 \%$ das crianças menores de cinco anos de idade apresentavam baixa estatura. Mostra, ainda, que $54 \%$ desses casos localizavam-se nas regiốes Norte e Nordeste, enquanto as regiốes Sul e Sudeste somavam menos de $\mathbf{2 0 \%}$.

Uma das evidências contidas no mapa da fome consiste na constatação de que o problema alimentar no Brasil não reside na disponibilidade e produção interna de grãos e dos produtos tradicionalmente consumidos no país, mas antes no descompasso entre o poder aquisitivo de ampla parcela da população e o custo de uma quantidade de alimentos compatível com as necessidades do trabalhador e de sua família.

Duas experiências recentes de combate à desnutrição em nível federal não tiveram melhor resultado do que os programas anteriores. A primeira delas, que consistia na distribuição de tickets para aquisição de leite no comércio, atingiu somente $36 \%$ das crianças desnutridas e $20 \%$ das crianças nordestinas não-des- 
nutridas. A segunda delas, bem mais recente, após um ano de vigência atende a apenas $10 \%$ dos municípios brasileiros atingindo uma população de 1,4 milhões de pessoas - sendo que, somente no Nordeste do país, existem cerca de cinco milhões de crianças menores de cinco anos vivendo em condições que envolvem riscos evidentes de desnutrição.

A formulação de uma Política Nacional de Segurança Alimentar, com vistas à qual foi elaborado o mapa da fome, representa uma iniciativa inovadora do Governo Federal, à medida em que seria implementada sob a coordenação do Conselho Nacional de Segurança Alimentar, composto por representantes do governo e por cidadãos representativos da sociedade civil. Tal iniciativa teve como fonte de inspiração a absolutamente inovadora experiência da Ação da Cidadania contra a Fome, a Miséria e pela Vida, movimento da sociedade civil que contou com a acolhida do Estado e, efetivamente, logrou significativos avanços na conscientização e mobilização da sociedade civil no combate à fome. Eis um exemplo bem-sucedido de uma experiência de nova parceria entre o Estado e a sociedade civil na busca de soluções para os problemas mais agudos da pobreza, a qual já envolveu três milhões de brasileiros em ações diretas e contou com a contribuição de outros 28.

\section{Emprego e mercado de trabalho}

O Brasil é um dos países que apresentou maior crescimento econômico neste século, sobretudo durante as três décadas e meia que se seguiram à Segunda Guerra Mundial. Seu PIB multiplicou-se por 11 e o seu produto industrial por 16.

O modelo de substituição de importaçóes, que levou a essa rápida industrialização, esgotou-se na transição entre as décadas de 70 e 80, quando sucessivos momentos de instabilidade econômica internacional exacerbaram o desequilíbrio externo da economia brasileira, produto da opção por uma estratégia de crescimento com endividamento. Teve início, então, um longo período em que as metas de saneamento dos desequilíbrios de curto prazo (ajuste do balanço de pagamentos) e o combate à inflaçáo predominaram sobre os objetivos de longo prazo. Foi no decorrer dessa última década e meia que a economia brasileira registrou seu pior desempenho macroeconômico deste século, tendo o PIB per capita diminuído em mais de 7\% entre 1980 e 1992 (tabela 19).

Não obstante, no mesmo período, a economia brasileira gerou 18 milhões de empregos - 15,8 milhões deles não agrícolas -, o que significa um incremento de 3,5\% ao ano, bastante superior à taxa de crescimento do produto, que foi da ordem de 1,5\% ao ano. Em compensação, nos últimos sete anos, os ganhos do trabalho na renda nacional não têm ultrapassado a margem de $30 \%$; os dados 
mais recentes informam que $\mathbf{5 2 \%}$ dos trabalhadores recebem, atualmente, menos de dois salários mínimos.

Mas embora o processo de industrialização acelerada não tenha sido suficiente para gerar empregos para todos nos setores modernos urbanos, o desemprego aberto não vem constituindo, tanto no início dos anos 80 como dos anos 90, o principal e mais agudo problema do mercado de trabalho brasileiro. Apesar do número absoluto de pessoas envolvidas, sua duração média e sua taxa continuam sendo reduzidas quando comparadas com a média internacional.

\section{O mercado de trabalho brasileiro}

Em 1981, a taxa de participação das pessoas com dez anos ou mais no mercado de trabalho correspondia a $54,23 \%$ (65,22\% para homens e $34,78 \%$ para mulheres). Os empregos no mercado formal de trabalho (com registro em carteira) respondiam por $42,19 \%$ da ocupação total. Os empregos no mercado informal de trabalho (sem registro em carteira), por $28,12 \%$. Os trabalhadores por conta própria correspondiam a $25,95 \%$ da ocupação total e a taxa de desemprego era de 6,5\% - nunca atingindo, no decorrer da década, taxas superiores a $8 \%$. Como se depreende dos dados coletados pelo Ibge para os anos de 91 e 93 , o percentual tende a permanecer neste patamar.

Apresentam-se, assim, como características do mercado de trabalho brasileiro no decorrer da década de 80:

- baixa taxa de desemprego aberto. Em 1991, ela já é de 4,1\%, em geral sistematicamente mais elevada entre os trabalhadores com nível de qualificação intermediário - de um a quatro e de cinco a oito anos de escolaridade formal (tabela 20).

- elevado grau de informalidade das relações de trabalbo. Tendendo a aumentar no decorrer da década e, mais acentuadamente, nos anos mais recentes.

- alta taxa de rotatividade da mão-de-obra, sobretudo para os trabalhadores menos qualificados. Também a duração média do desemprego tende a aumentar ao longo da década: a maior freqüência passou de menos de um més, em 1981, para de quatro a 12 meses, em 1990. Por outro lado, evidencia-se uma tendência de aumento da duração média do último emprego antes de o trabalhador ficar desempregado.

- baixa intensidade e forte desigualdade em termos de capital humano. Em 1990, o número médio de anos de escolaridade de um membro da PEA acima de 25 
anos de idade era de quatro anos; $11,3 \%$ dentre eles haviam chegado à universidade, $34 \%$ dos adultos permaneciam analfabetos.

- grande heterogeneidade de situaçóes de emprego e trabalho, em termos de acesso a renda e a direitos trabalhistas e beneficios sociais:

- emprego no mercado formal de trabalho: significa ter direito a salário mínimo, a jornada fixa de trabalho, a férias remuneradas, ao acesso à previdência social e, em média, a uma remuneração mais elevada do que a propiciada por segmentos informais. Nesta situação, a dinâmica dos salários nominais, em grande medida, é determinada pelo governo mediante políticas salariais. No decorrer da década, nenhuma das fórmulas adotadas logrou evitar a erosão dos salários reais dos trabalhadores do mercado formal, decorrência do processo inflacionário.

- emprego no mercado informal de trabalho: significa que o contrato de trabalho se dá à margem da legislação trabalhista, podendo, portanto, ser rompido mais facilmente; ao mesmo tempo, o trabalhador não tem assegurados os direitos previstos naquela legislação nem os benefícios vinculados à previdência social - mesmo após a Constituição de 1988, que universaliza o direito à seguridade social. Trata-se de um mercado mais competitivo, no qual a renegociação dos contratos de trabalho é feita com maior facilidade. Embora, por essas características, os salários reais desses trabalhadores sejam relativamente menos sensíveis aos surtos inflacionários do que no caso anterior, acabam revelando-se mais sensíveis com relação aos ciclos econômicos de longo prazo.

- trabalhadores por conta própria: tal situação caracteriza ampla gama de situaçôes, do pequeno e médio empresários a prestadores de serviços e comércio ambulante. Apesar do alto grau de competitividade presente nestes casos, apresentam maior capacidade relativa de defesa de seus rendimentos frente à inflação.

É exatamente essa heterogeneidade de situaçóes, associada ao alto grau de rotatividade e à elevada presença do setor informal, que imprime grande elasticidade ao mercado de trabalho brasileiro, bem como explica a extraordinária capacidade da economia brasileira para geração de empregos, traduzida nas relativamente baixas taxas de desemprego aberto.

\section{O mercado de trabalho informal}

No que se refere ao alto grau de informalidade do mercado de trabalho brasileiro, nele parece residir uma das principais razões para a taxa de desemprego 
aberto ter se mostrado pouco sensível às flutuaçóes do nível de atividade econômica no decorrer dos anos $\mathbf{8 0}$, dada a capacidade dos segmentos informais do mercado de trabalho absorverem mão-de-obra liberada pelo segmento formal. A evolução dos dados relativos à composição do emprego por posição na ocupaçáo nesse mesmo período não permite, no entanto, identificar uma tendência clara de informalização do mercado de trabalho, a não ser pelo aumento significativo da participação dos empregadores (criação de um grande número de pequenas e médias empresas).

Já no início dos anos 90 , porém, constata-se drástica mudança no perfil do mercado de trabalho brasileiro, que passa a registrar aumento muito acentuado da participação dos segmentos informais na ocupação total. A informalidade no mercado de trabalho passa a ser uma alternativa real - e uma contrapartida - à forte queda da participação dos trabalhadores formais na força de trabalho. De 1989 a 1992, o aumento das situaçốes informais no mercado de trabalho foi superior a $8 \%$.

Em tese, para cada posto de trabalho a menos no setor formal corresponderia um posto a mais no setor informal: nas regióes metropolitanas do Sul e do Sudeste do país têm maior presença os trabalhadores por conta própria, enquanto na região Nordeste é relativamente mais importante a presença de empregados sem carteira de trabalho assinada (tabela 21 ).

Os determinantes desse aumento do segmento informal no mercado de trabalho são múltiplos. Dentre eles, o aumento dos encargos trabalhistas introduzido pela Constituição de 1988, o longo período de recessão econômica (desde 1987 a economia brasileira não crescia dois anos seguidos, como ocorreu em 93 $-4,1 \%$ do PIB - e $94-4,6 \%$ do PIB), o descrédito no poder de fiscalização do Governo (o risco de os empregadores não cumprirem a legislação trabalhista é bastante baixo) e, sobretudo, o imperativo de as empresas se tornarem mais competitivas diante da abertura da economia, a partir de um processo de reestruturação industrial quase sem investimento em automação. Pelo processo, enfim, de mudança de paradigmas da produção: o taylorismo e o fordismo sendo substituídos pela flexibilização; as economias de escala pelas economias de escopo, o que corresponderia a mudanças nos perfis ocupacionais e na organização do processo de trabalho.

As consequïéncias desse aumento da informalidade consistem em evidente fragilização das relações trabalhistas e o decorrente agravamento das características da pobreza. Da mesma forma que as situaçóes de pobreza não decorrem exclusivamente da não inserção no mercado de trabalho, aparecendo também em casos de inserção precária (e até mesmo em casos de inserção no mercado formal, no geral, associada à desqualificação profissional), desta precariedade 
derivam outras conseqüuências, ligadas à maior rotatividade do emprego e, sobretudo, à ausência de formaçáo profissional no ambiente de trabalho, o que, de certa forma, permitiria a esse segmento de trabalhadores superar suas desvantagens iniciais.

\section{Composição setorial do emprego}

Durante a década de $\mathbf{8 0}$ observou-se redução da importância relativa dos setores primário e, com menor intensidade, secundário na ocupaçáo total; em contrapartida, aumento acentuado da participação do setor terciário.

Enquanto a participação do setor agrário na ocupação total caiu cerca de seis pontos percentuais, e o setor secundário manteve a participação da indústria, tendo apresentado queda de dois pontos percentuais na construçáo civil, o setor terciário apresentou aumento de cinco pontos. Isso deveu-se, sobretudo, ao aumento dos pesos relativos da administração pública $(1,5 \%)$, do comércio $(2,5 \%)$ e, principalmente, dos serviços privados $(4,0 \%)$. O setor financeiro foi o único, no terciário, a năo aumentar sua participação relativa no emprego, apesar do aumento substancial da sua participação na renda (tabela 22).

\section{Salário médio real}

Ao longo da década de 80 o salário médio real sofreu uma redução de $14 \%$ (gráfico 5). Grande parte dessa perda ocorreu na primeira metade da década, em decorrência da perversa conjugação de recessão econômica e aceleração do processo inflacionário; nova - e mais abrupta - tendência à queda ocorreu no início dos anos 90. Dados relativos às seis principais metrópoles brasileiras registram, entre 1989 e 1992, uma queda do salário real médio superior a $40 \%$.

Esses resultados indicam que a contrapartida da grande quantidade de empregos gerada nesse período foi a má qualidade dos mesmos. Ou, em outras palavras, ao longo da última década e meia o estancamento do crescimento econômico, se não inibiu o crescimento de empregos, comprometeu a qualidade dos mesmos.

Embora os salários relativos tenham flutuado consideravelmente, nos anos 80 , a queda do salário real médio foi mais pronunciada entre trabalhadores de qualificação média e baixa do que entre os melhor qualificados, utilizando-se aqui como critério anos de escolaridade. Tomando-se o ano de 81 como índice igual a 100 , a queda do salário real dos trabalhadores com menos de um ano de instruçáo foi de 19 pontos; daqueles com cinco e oito anos de instrução foi de 20; e daqueles com mais de 11 anos de instrução foi de nove pontos. Tem-se, portanto, que 
o diferencial de renda entre diferentes níveis de escolaridade aumentou substancialmente durante a década (tabela 23).

Mas, apesar de o processo de flexibilização segmentar ainda mais o mercado de trabalho, diferenciando, dentro de uma mesma empresa, os trabalhadores de seu núcleo duro - tecnológico - daqueles que se dedicam a atividades rotineiras e repetitivas, e que reproduzem, em qualquer empresa, fora do abrigo dos contratos coletivos, as condiçóes gerais de fragilidade, baixa remuneração e alta rotatividade das relações de trabalho, no período mais recente (início da década de 90), o custo do ajuste macroeconômico passa a recair predominantemente sobre os trabalhadores mais qualificados.

Assim, é no setor industrial - tido como tipicamente moderno - que os trabalhadores registram a maior retração dẹ suas rendas reais médias, com perdas superiores às dos trabalhadores no setor agrícola, as quais, por sua vez, se comparam às perdas dos empregados no setor financeiro. Tomando-se, uma vez mais, $o$ ano de 81 como índice igual a 100, a perda dos setores agrícola e financeiro foi de 15 pontos, a da indústria de 20 , a da administração pública de três, e a dos serviços privados de dois pontos. O comércio termina a década com o mesmo índice, enquanto o setor da construção civil ganha cinco pontos.

O mesmo fenômeno se repete quando se examinam as perdas da renda real média por posição na ocupação. A experiência brasileira da última década contraria grande parte da literatura que sustenta que o diferencial de salários a favor dos trabalhadores formais tenderia a aumentar em períodos de recessão. No Brasil, ocorreu o oposto: no decorrer da década de 80, os trabalhadores do segmento informal do mercado de trabalho, incluídos aí os empregados sem carteira assinada, revelaram maior capacidade de defesa de seus rendimentos reais do que os trabalhadores do setor formal. Tomando-se $o$ ano de 1981 como equivalente a 100 , no período de 1990, a perda dos trabalhadores com carteira de trabalho assinada foi de 19 pontos, enquanto trabalhadores informais apresentaram um ganho de dez pontos. Da mesma forma, as maiores perdas ao longo do processo de ajuste estrutural do final da década de 80 e início da de 90 ocorreram nos setores de assalariamento formal, dos trabalhadores por conta própria e dos empregadores, demonstrando, uma vez mais, que o setor do assalariamento informal apresentou maior capacidade de defesa de sua renda real (tabela 24).

O processo de deterioração da qualidade do emprego que vem sendo detectado, contudo, não se traduz somente na precariedade das garantias trabalhistas e do acesso aos benefícios sociais, ou na maior instabilidade dos postos de trabalho. Outra de suas facetas reside no aumento da insegurança das situaçóes de trabalho. Embora em números absolutos a década de 80 tenha apresentado queda na ocorrência de acidentes do trabalho, nos últimos anos vem-se registrando au- 
mento da ocorrência relativa de doenças profissionais e incapacidade permanente. Neste último caso, elas passam de $2,4 \%$ para $3,4 \%$ do total de acidentes (excluídos sempre os acidentes de trajeto) e, no caso das doenças profissionais, de $0,5 \%$ para $1 \%$, dados relativos aos anos de $1989 \mathrm{e} 1991$. Nos dois primeiros anos desta década, o país apresenta um índice de 77 mortes por cada dez mil acidentes de trabalho, taxa muito elevada quando comparada a outros países.

\section{Disparidades de niveis de rendimento}

O mercado de trabalho brasileiro continua altamente diferenciado em termos de níveis de rendimento por gênero. A integração da população feminina economicamente ativa no mercado de trabalho acontece em situação de acentuada iniqüidade: dados de 1988 revelam que, em média, o salário das mulheres representava $54,1 \%$ do salário dos homens, e que $73 \%$ das trabalhadoras percebiam até dois salários mínimos.

Dados do ano de 1990 revelam, por sua vez, que 61\% das mulheres ocupadas percebem até dois salários mínimos ( $49 \%$ no caso dos homens); $24 \%$ delas percebem de dois a dez salários mínimos ( $37 \%$ no caso dos homens); enquanto apenas 3\% das mulheres percebem mais de dez salários mínimos, esse percentual chega a $7 \%$ no caso dos homens.

Se a esse fato associar-se que no ano de 1989 foram identificadas $7,3 \mathrm{mi}$ thóes de mulheres chefiando domicilios (dentre as quais $30 \%$ sem nenhuma fonte de rendimento), e que mais de $60 \%$ dentre elas percebiam até dois salários mínimos e tinham mais de dois filhos, confirma-se a hipótese de que o diferencial de rendimento mensal por gênero no atual padrão de inserçáo no mercado de trabalho, por desfavorecer as mulheres, faz com que as unidades familiares matrifocais constituam importante foco de pobreza absoluta.

O mesmo fenômeno de disparidades de rendimento médio mensal ocorre entre os meios urbano e rural. Selecionam-se a seguir alguns dados. Enquanto, na área urbana, o rendimento médio mensal de trabalho das pessoas ocupadas é de cinco salários mínimos, na área rural ele se reduz para 1,6 salários mínimos. A área urbana apresenta uma taxa de atividade das crianças entre dez e 13 anos de $8,3 \%$; já na área rural, esta se eleva para $27,8 \%$. E se na área urbana a população ocupada com rendimento do trabalho inferior a um salário mínimo é de $15,6 \%$, na área rural esse percentual chega a $31 \%$.

Ocorrem, ainda, diferenciais acentuados de rendimento nominal médio mensal de trabalho das pessoas ocupadas por cor. Para o país como um todo, o rendimento nominal médio mensal é de 4,1 salários mínimos; dentre a população branca, de 5,3 salários mínimos, enquanto para a população preta ou 
parda é de 2,5 salários mínimos, sofrendo uma diminuição de mais de $\mathbf{5 0 \%}$ (tabela 25).

Em termos regionais os diferenciais do rendimento médio mensal por cor estão igualmente presentes, embora sejam menores na região Nordeste do que na Sudeste, por exemplo. Enquanto para a região Nordeste a média geral é de 2,2 salários mínimos, dentre os brancos é de 3,4 e dentre os pretos e pardos de 1,8. Já para a região Sudeste, para uma média geral de 5,1 salários mínimos, dentre os brancos ela é de 6,1 e dentre os pretos ou pardos de 2,9. Em média, portanto, o rendimento nominal médio mensal de trabalho das pessoas pretas ou pardas ocupadas é de aproximadamente metade (47\%) daquele das pessoas brancas ocupadas. Note-se que essa diferença é menor na regiāo Nordeste (53\%), tendendo a se acentuar na Sudeste (57\%).

\section{Dindmica e estrutura do mercado de trabalbo brasileiro}

A capacidade de criação de empregos da economia brasileira no decorrer da década de 80 , bastante superior à taxa de crescimento do produto $(3,5 \%$ a.a. e $1,5 \%$ a.a., respectivamente), fez-se acompanhar de uma queda de cerca de $17 \%$ na produtividade do trabalho, de uma redução de $14 \%$ no salário real, e de quase $50 \%$ no salário mínimo real entre os anos de 80 e 90.

Esse processo teve como um de seus componentes marcante deteriorafäa da qualidade dos empregos gerados no período: boa parte deles concentram-se no setor informal e na pequena empresa (de 33,7\%, em 1980, para 54,1\%, em 1992), sendo que a participação das grandes empresas apresenta movimento inverso (de $55,2 \%$ para $35,4 \%)$.

Nesse período, o perfil da população ocupada indica elevação do nível de escolaridade, envelhecimento da força de trabalho, maior parcela da força de trabalho feminina e maior concentração no setor terciário da economia, no qual se tem abrigado boa parte dos postos de trabalho informais. Além disso, continua significativa a taxa de participação do grupo de crianças e adolescentes (dez a 17 anos) que trabalham $(11,6 \%$, em 1990); o custo social deste trabalho precoce, na maior parte das vezes em situaçóes de emprego caracterizadas pela absoluta precariedade, é extremamente alto: compromete-se a qualificação da força de trabalho, inviabiliza-se a mobilidade social no interior de uma mesma geração e, sobretudo, perpetua-se a pobreza entre geraçóes.

Há evidências de que a famillia brasileira vem estimulando o aumento da inserção de seus membros no mercado de trabalho, parte da estratégia de compensar o desemprego aberto, o subemprego, a precarização das situaçóes de tra- 
balho e, principalmente, a queda do salário real experimentada pelos chefes de família no decorrer da década.

Nesse período o setor público atuou, de certa forma, com uma política compensatória de emprego, ampliando a sua participação relativa na distribuição setorial de pessoas ocupadas de $8 \%$, em 1981, para 9,7\%; em 1990 o comércio ambulante também representou essa função, ao apresentar um incremento de $91,3 \%$ em sua participação relativa.

No mesmo período, a inserção das mulheres no mercado de trabalho apresentou ampliação significativa ( $35,6 \%$ da PEO, em 1990), acompanhada de uma diversificação dos postos de trabalho femininos. Mas, apesar de uma taxa média anual de crescimento da participação das mulheres em ocupações de nível superior e gerenciais em torno de $\mathbf{1 0 \%}$ a.a., foram as ocupaçóes manuais de menor qualificação as responsáveis por mais da metade $(51,8 \%)$ do incremento absoluto da sua participação no mercado de trabalho urbano.

Vale notar, no entanto, que, apesar de existirem evidências de seletividade do mercado de trabalho contra mulheres solteiras e sem experiência, e da menor remuneração do trabalho feminino, a evolução dos rendimentos por sexo revela uma variação proporcional (cerca de 10\%) para homens e mulheres no decorrer da década, mas em sentido contrário: declina o rendimento médio dos homens e eleva-se o das mulheres.

Há suficientes epidências, portanto, de que o mercado de trabalho brasileiro é extremamente flexivel, ou seja, tem capacidade de se ajustar rapidamente a choques exógenos sem gerar elevadas taxas de desemprego aberto. Esse elevado nível de flexibilidade, porém, vem acompanhado de crescente participação de trabalhadores informais, sem acesso a direitos trabalhistas e, no geral, com rendimentos inferiores àqueles do setor formal.

Tal flexibilidade também deriva, por outro lado, da crescente terciarização da força de trabalho, implicando acentuada concentração da população ocupada em setores onde a mão-de-obra é abundante e sub-remunerada.

Paralelamente, contudo, postos de trabalho precários, sub-remunerados e sem perspectiva de mobilidade vertical também foram gerados no seio do setor formal. Há evidências de que, além da terciarização e da informalização do assalariamento como parte do processo de reestruturaçáo das empresas, estão surgindo novas formas de contrato de trabalho visando a flexibilizar ainda mais o emprego.

Isso indica, por sua vez, que os próprios mecanismos institucional-legais de regulação do trabalho, associados a características do mercado de trabalho, acabam 
por incentivar contratos de curta duração, criação de postos de trabalho que exigem baixa qualificação, baixo investimento em treinamento específico e, em conseqüência, baixa produtividade. Constitui exemplo desse fenômeno a forma como vêm sendo utilizados o Fundo de Garantia por Tempo de Serviço e o Seguro Desemprego.

Uma das principais características da flexibilidade do mercado de trabalho consiste na relativa facilidade com que os trabalhadores mudam de emprego. No Brasil, a rotatividade do trabalho é bastante elevada: em média entre 30 a $40 \%$ dos postos de trabalho do setor formal mudam de mão a cada ano. No mercado de trabalho como um todo, os trabalhadores ficam desempregados, em média, três vezes ao ano, permanecendo cada vez aproximadamente 1,6 meses nessa situação.

No Brasil, não só o custo de demissão dos empregados é relativamente baixo, como também existe um forte apelo para que os trabalhadores prefiram contratos de curto prazo. No primeiro caso, porque os custos, além de baixos, são apenas monetários; no segundo, porque as indenizaçóes financeiras da demissão representam um reforço imediato no orçamento do trabalhador (quer pela retirada do Fundo de Garantia, quer pela possibilidade de poder associar o Seguro Desemprego a outro emprego, dada a baixa fiscalização e a ausência de contrapartidas por parte do trabalhador).

Cria-se, então, no âmbito da dinâmica de flexibilização do mercado de trabalho, um mecanismo perverso: do ponto de vista do trabalhador, contratos de curto prazo apresentam vantagens monetárias imediatas; do ponto de vista do empregador, a melhor estratégia consiste em extrair o máximo do trabalhador neste breve espaço de tempo, em detrimento da opção de investir nele a médio e longo prazos dado o alto risco de a empresa perder o investimento realizado. Por essa lógica, incentiva-se uma aliança entre trabalhadores e empregadores, no sentido de acentuar ainda mais o processo de informalização das relações de trabalho.

Em consequiência, sendo a relação de trabalho e os empregos altamente precários - é o que se denominou anteriormente como a deterioração da qualidade dos empregos -, sobra pouco espaço para o crescimento da produtividade do trabatho por meio de treinamento e aprendizagem no emprego, os quais não são práticas comuns no mercado de trabalho brasileiro. Levantamento recente da Confederação Nacional da Indústria revela que apenas $40 \%$ da força de trabalho industrial possui o curso primário completo; $30 \%$ são analfabetos e $30 \%$ possui alguma instrução, mas não é capaz de interpretar corretamente manuais de trabalho. Este último segmento, que poderia operar eficientemente no paradigma industrial anterior, certamente não corresponde às exigências do novo paradigma.

Restam, então, duas possibilidades: a coexistência de dois tipos de trabalhadores no interior de uma mesma empresa - os relativamente estáveis, nos 
quais os investimentos em treinamento seriam elevados, e os pouco qualificados, com contratos curtos ou temporários; ou empresas que evitam sistematicamente investir em treinamento, optando por tecnologia pouco intensiva em mão-deobra qualificada no contexto do binômio baixa produtividade e baixos salários. Ambos os tipos de empresas estão presentes no mercado brasileiro, sendo que as grandes empresas talvez estejam mais próximas do primeiro tipo, enquanto as pequenas, do segundo.

Mas é exatamente pelo fato de as perdas da década de 80 e início da de 90 terem recaído mais sobre uns setores que sobre outros (empregados particulares, homens e contribuintes da previdência social), ao mesmo tempo em que, aumentando a concentração de renda nos extratos superiores da pirâmide de distribuição, aprofundavam-se as desigualdades sociais (na medida que, entre outros fatores, as transformaçóes do mercado de trabalho frente à globalização e internacionalização da produção e ao novo paradigma correspondente promoveram um processo de nivelamento por baixo), que as questôes da educação e da formação profissional ganham importância.

\section{Sistema educacional e formação profissional}

As características do atual processo de desenvolvimento tecnológico impóem novos desafios, com ênfase na questão dos recursos humanos, à medida em que a própria capacitação tecnológica implica capacidade de gerar inovaçóes de produtos e processos a partir do envolvimento dos próprios trabalhadores.

Tais mudanças trazem profundas consequiências no que se refere a perfis ocupacionais e organização do trabalho, apontando para um acesso ao mercado de trabalho qualificado determinado cada vez mais por critérios de seletividade definidos, de um lado, por nova concepção de processo educacional e, de outro, por nova visão de formação profissional.

Essas transformações implicam a necessária distinção entre o conceito de educação técnica, como sinônimo de formação profissional, e o novo conceito de educação tecnológica, significando aquisição de uma formação sólida, baseada em conteúdos gerais, que servirá de apoio aos vários níveis de qualificação, e também a uma formação profissional ampla, em todos os níveis, de modo a permitir ao trabalhador acompanhar as mudanças, cada vez mais freqüientes, do padrão tecnológico.

Como no Brasil o que ocorre é a superposição dos problemas novos do mundo do trabalho e dos problemas de caráter mais estrutural da informalidade e do peso das profissões pauperizadas, a não universalização das novas formas 
de capacitação condenará um segmento importante da população a postos de trabalho de baixa qualidade, caracterizados pelo exercício de tarefas rotineiras, ampliando a fragmentação, a heterogeneidade e a segmentação já existentes. Os dados anteriores atestam que nem o emprego nem o nível educacional obtidos por meio dos padróes tradicionais de formaçáo representam defesa eficaz contra a pauperização e a situação de vulnerabilidade social.

A realidade brasileira caracteriza-se, nesse particular, por um déficit de formação geral, o qual pode representar sério entrave para a generalização do novo padrão tecnológico no país, reforçando o processo de crescente deterioração da qualidade dos empregos, como visto. A esse déficit associam-se carências e universalização do ensino, sobretudo no nível secundário, além de sua ineficiência.

No que se refere aos oito anos de ensino básico, apenas $34 \%$ dos que nele ingressam chegam à sua conclusão, no geral com um tempo de permanência $50 \%$ maior do que o período previsto. Existem também descompassos entre a oferta e a demanda, estimando-se em quatro milhões o número de crianças fora da escola, ao mesmo tempo que se verifica uma sobrecarga da rede pública. Apenas $1 \%$ da população chega à universidade. $O$ ensino de segundo grau (do $9^{\circ}$ ao $11^{\circ}$ anos) representa outro grande ponto de estrangulamento, já que somente $30 \%$ da população entre 15 a 19 anos de idade tem acesso a ele.

Por outro lado, às escolas técnicas públicas têm acesso majoritário setores economicamente mais favorecidos, com a consequiência óbvia da perda de importância de sua terminalidade - capacitação profissional -, à medida em que passam a funcionar como preparo para ingresso nas universidades. Às universidades públicas, assim, passam também a ter acesso majoritário as camadas de maior renda.

A esse quadro acrescente-se a baixa remuneração, a desvalorização do magistério, a crise de formação e a ausência de reciclagem dos professores.

Todos esses fatores conjugados criam um paradoxo que consiste no déficit de formaçáo geral vir associado a uma rede relativamente extensa, se bem que deteriorada, de equipamentos de ensino básico, sem contar a subutilização dos serviços de educação, caracterizada pelos altos índices de repetência e abandono das escolas - sobretudo para ingressar precocemente no mercado de trabalho com o objetivo de auxiliar no orçamento doméstico. Pouco qualificados, esses menores encontram-se, no geral, em situaçóes de emprego informais com pouquíssimas, senão nulas, chances de ascensão e treinamento no trabalho; ao passo que, se tivessem permanecido no sistema escolar, ingressariam posteriormente no-mercado de trabalho com maior estoque de capital humano, melhor habilitados, portanto, para responder às exigências do novo padrão tecnológico. 
Nesse sentido, reformulação e melhoria da qualidade do ensino, associadas a medidas visando à diminuição drástica da participação de crianças e adolescentes no mercado de trabalho, podem representar fatores centrais na busca do alívio e da superação da pobreza. Da mesma forma, a associação da criação de empregos produtivos, de melhor qualidade, com a promoção de maior estabilidade dos contratos de trabalho afigura-se imprescindível para que se realizem maiores investimentos em capital humano.

Caso contrário, nem o crescimento econômico, nem a geraçáo de empregos estarão contribuindo para o combate à pobreza, como atesta a experiência brasileira recente. Para reverter esse quadro; tornam-se essenciais a melhoria da qualidade da educação (nas duas acepçóes anteriormente mencionadas) e a diminuição da desigualdade de oportunidades na formação de capital humano, sem falar na busca por maior eficiência e eficácia do aparato estatal, tanto no que diz respeito às políticas de caráter distributivo como àquelas de caráter redistributivo, por meio das quais se transfiram recursos para as camadas mais pobres da população. Neste ponto específico, ganham relevo as políticas sociais como mecanismo privilegiado de integraçáo social.

\section{Integração social e políticas sociais}

Num mundo moldado pela reestruturação produtiva em escala global, a realidade social brasileira demanda respostas urgentes e inovadoras. $O$ maior desafio consiste em alçar à condição de cidadãos o contingente de pobres estruturais, herança do padräo de desenvolvimento econômico denominado industrializạ́á̃o protegida, que se esgotou nos anos 80 . A esses, associam-se os nopos pobres, produto da crise econômica e do persistente processo inflacionário da década de 80.

Assim, da mesma forma que no Brasil contemporâneo superpöem-se problemas novos do mundo do trabalho e problemas mais estruturais da informalidade e das profissóes pauperizadas, superpóem-se, também, situaçóes estruturais de pobreza e situações de pobreza de grupos que, diante das recentes transformaçóes econômicas, deixam de ter acesso a condiçóes de vida que os definiam anteriormente como não-pobres.

Por outro lado, vimos que uma situação de pobreza não se define somente pelo não-acesso a níveis de rendimento que permitam a satisfação das necessidades básicas dos indivíduos no espaço privado. A condição de pobre tende a estar associada à situação de carente e ao fato de pertencer a grupos vulneráveis, vítimas de discriminaçóes de toda ordem, também no plano simbólico da cultura, que normatiza os padrões de sociabilidade. São exatamente esses grupos que devem receber atenção imediata, passando a constituir o público-alvo de um con- 
junto articulado de açóes que visem a discriminá-los, agora positivamente. A contrapartida, portanto, da situação de pobreza e dos grupos sociais marginalizados deve ser a integração social, com o objetivo de criar condiçóes não só para aliviar, como também superar a pobreza.

É consenso que a redução do contingente de brasileiros que vivem em situação de pobreza (sem esquecer que vivenciam essa situação de formas diferenciadas, compondo uma ampla variedade de grupos vulneráveis) requer a retomada do crescimento econômico do país. Essa retomada, no entanto, deve ocorrer a partir de um novo modelo de desenvolvimento e em níveis tais que permita ofertar empregos - e aí o setor agrário, tanto quanto os demais, joga um papel fundamental - capazes de reabsorver produtivamente quem foi desempregado, bem como empregar novos contingentes, quer dentre os pobres estruturais quer dentre as coortes demográficas que estão ingressando na faixa etária produtiva.

Nesse sentido, as políticas econômicas passam a assumir também a dimensão de políticas sociais, à medida em que parte significativa dessas características macroestruturais decorrem das políticas governamentais, embora não exclusivamente (haja visto as amplas mudanças sociais que vêm ocorrendo a partir da reestruturação do setor privado - e o movimento no sentido da descentralização do processo produtivo guarda grande margem de autonomia com relação a essas políticas).

Assumir a possibilidade de retomada do crescimento econômico conforme um novo modelo que seja integrador e crie empregos produtivos significa não se render à lógica do mercado - com suas características excludentes - nem tampouco desconhecê-la, à medida em que a dinâmica do mercado tende a aumentar o grau de polarização social, em grande parte proveniente da própria estrutura da rede produtiva.

Enfrentar de maneira eficaz a questão da pobreza implica, portanto, matizar a tradicional oposiçáo entre desenvolvimento econômico e desenvolvimento social, buscando uma articulação entre ambos. Em consequiuência, superar a concepção de políticas sociais restrita a seu caráter compensatório das desigualdades sociais geradas pelo mercado. Mais que isso, assumir a própria dimensão econômica das políticas sociais, quer como geradoras, elas próprias, de emprego, quer como promotoras de novas oportunidades de investimento, a partir da demanda de produtos do setor produtivo.

Por outro lado, dadas as dimensões do fenômeno da pobreza no Brasil, bem como sua complexidade (vale dizer, as diferentes formas que assume em situaçóes concretas de sobrevivência, traduzidas numa densa rede de discrimina- 
ções), a mera identificação dos grupos socialmente mais vulneráveis, com o objetivo de formular políticas pontuais, tem implicação grave. É que, ao se permanecer no campo da necessidade imediata, corre-se o risco de implementar políticas que reproduzam o presente padrão de discriminação social, até pelo já assinalado mal crônico da ineficiência e ineficácia que as caracteriza.

Ineficiência: o atual perfil do sistema brasileiro de proteção social caracteriza-se, primeiro, por significativo gasto na área social (durante a década de 80, próximo de $18 \%$ do PIB); segundo, por um aparato institucional gigantesco, responsável por políticas e programas sociais setoriais desconexos, afetados por alto grau de centralização e superposição de clientelas, altamente onerosos e, quase sempre, regidos pela lógica contábil da disponibilidade residual de recursos financeiros frente às demandas econômicas.

Ineficácia: cálculos do Banco Mundial relativos a meados da década de $\mathbf{8 0}$ estimam que somente $10 \%$ dos recursos empregados em programas sociais atingiam seu público alvo; e que os mais pobres - quase um quinto da população recebiam apenas $7 \%$ do total de benefícios, enquanto, no outro extremo, os $4 \%$ de maior renda recebiam cerca de $\mathbf{1 8 \%}$ do total de benefícios. Esses dados reforçam os anteriormente apontados, mostrando que os programas sociais atingem proporcionalmente mais os menos pobres dentre os pobres, além de significativa proporção dos não-pobres.

Não cabe aqui reconstituir as raízes históricas desse perfil. Dentre as heranças do processo de desenvolvimento recente do Brasil, contudo, destaca-se a significativa participação do setor privado no segmento de serviços, lucrativos ou não-lucrativos, cujo crescimento foi propiciado exatamente pelas políticas governamentais. Pois, a garantia da procura cativa desses serviços pelo Estado mediante a compra, direta ou indireta por meio de subsídios, exime a oferta das regras clássicas da concorrência de mercado. A privatização da saúde e da educação, exemplos claros, não se sustentariam fora de sua estreita articulação com a política social do Estado. Como resultado, a lógica do mercado sobrepóe-se à lógica dos direitos sociais e, portanto, à lógica do acesso da população pobre a bens e serviços essenciais.

Por outro lado, do ponto de vista do financiamento do setor social, uma das questōes básicas reside na constatação de que recursos não gastos em escala suficiente certamente são mal gastos. Outra consiste na própria composição dos recursos. A partir da Constituição de 1988, que ampliou os direitos sociais e descentralizou a responsabilidade pela formulação e implementação de políticas nessa área, sacrificando parcela de recursos fiscais retidas pela União em favor dos estados e municípios, vêm ocorrendo dois fenômenos paralelos. 
Em primeiro lugar, uma tendência geral, mais acentuada em alguns setores (como a saúde) do que em outros (como a educação), de aumento de dispêndio dos orçamentos municipais na área social, concomitantemente à retração dos dispêndios estaduais nesses mesmos setores. Além disso verificam-se alteraçóes no que se refere à composição dos recursos federais destinados à área social. $O$ orçamento federal é composto por contribuiçóes sociais e recursos fiscais. Enquanto, em média, as primeiras sustentaram $70 \%$ do gasto social no decorrer da

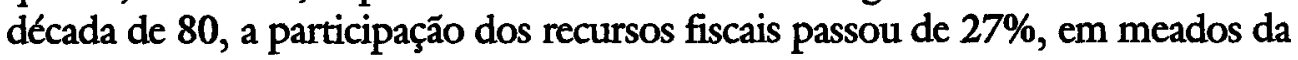
década, para $38 \%$ no final desse período. Na verdade, como as contribuiçōes sociais têm sua base quase que exclusivamente na folha de salários, em havendo perda da representatividade do vínculo de assalariamento na massa total de salários, torna-se cada vez mais necessário o aporte de outras fontes de financiamento. Secundariamente, como esses encargos sociais representam custo adicional de produçáo, a prática vigente é o seu repasse para o preço final dos produtos, o que onera duplamente os assalariados, isentando, na prática, os empregadores.

Outro fator a se considerar refere-se ao fato de as contribuiçóes sociais terem seus recursos já vinculados a clientelas específicas (seja sob a forma de prestações em dinheiro, seja sob a forma de serviços), ao passo que os recursos fiscais não têm essa característica, estando sua destinação vinculada a decisóes políticas de cada governo. Mas, se isso, em princípio, poderia conferir maior flexibilidade aos gastos na área sociál, por outro lado, imprime alto grau de descontinuidade às políticas sociais. A questão de fundo que se apresenta, consequientemente, é de como imprimir maior continuidade aos programás e políticas sociais. Estes, ao ficarem na dependência estreita de conjunturas políticas, acabam, na melhor das hipóteses, configurando-se como programas emergenciais, com alta vulnerabilidade ao clientelismo, ou ainda como políticas insuficientemente distributivas.

O Brasil enfrenta, portanto, as dificuldades inerentes a buscar convergência entre duas lógicas de proteção social: a das políticas de caráter universal, destinadas ao conjunto dos cidadăos $\mathrm{e}$ financiadas basicamente por recursos fiscais, $\mathrm{e}$ a das políticas de proteção a grupos específicos, financiadas por contribuiçóes sociais. No último caso, $o$ acesso à proteção social não como um direito, mas como um privilégio. A difícil convivência dessas duas lógicas adiciona dramaticidade a nossa realidade social, implicando necessidade de enfrentar-se um conflito distributivo de complexa solução.

A polarização de interesses opostos em torno das expectativas de proteção social, cujo núcleo central de tensão e disputa reside nas distintas lógicas de seu financiamento (as quais, em última análise, resumem-se em quem vai pagar a maior parte da conta), traduz-se num movimento pendular entre uma visão diretamente contributiva (vinculada ao assalariamento formal e ao trabalho qualifica- 
do) e uma visão voltada para a cidadania, que pressupõe a universalidade do acesso aos direitos sociais, tendo como referência uma base fiscal de financiamento. Tal debate, ao mesmo tempo em que traz a questão do sistema de seguridade social para o foco central da disputa orçamentária por receitas, integra-a também ao debate sobre a reforma tributária e a relação Estado/mercado na área social.

Aqui faz-se necessário distinguir o público do estatal. Da mesma forma que não se pode atribuir unicamente às políticas de proteção social a solução das questóes da pobreza e das extremas desigualdades sociais, não se pode declinar da responsabilidade do Estado no que tange à garantia dos direitos do cidadão. Isso não significa, no entanto, que os serviços sociais tenham de ser executados exclusivamente por instituições estatais. Significa que, seja qual for a instituição executora, eles têm o estatuto de um serviço público e, como tal, devem estar sob controle público.

Igualmente falacioso seria pensar que, por si só, o mercado possa cumprir a função de proteçáo social. Isso seria contraditório com a lógica de maximização dos ganhos - em certo sentido, o próprio mercado de trabalho seria fonte geradora de discriminações, ou, no mínimo, incapaz de eliminá-las. É fácil encontrar numerosos casos nos quais variada gama de discriminaçóes continuam prevalecendo, por exemplo, no mercado de trabalho em que pese a moderna e atualizada legislação trabalhista brasileira.

A lógica do mercado, portanto, revela-se incompatível com a responsabilidade por políticas e programas sociais compensatórios de desigualdades sociais, em última instância geradas pela própria dinâmica da economia de mercado. Direitos sociais com equiidade implicam sua garantia mediante um sistema articulado de políticas sociais, que busque desmercantilizar os benefícios e serviços sociais básicos, desvinculando seu acesso da inserção no mercado de trabalho. Daí fazer-se necessária a distinção entre público e estatal: a responsabilidade pela garantia dos direitos sociais e por políticas e programas de alívio é superação da pobreza é essencialmente pública, devendo estar sob controle público sua execução, seja por instituições e serviços estatais, seja por instituições privadas, lucrativas ou não-lucrativas. Caso contrário, as políticas sociais seguiriam sendo ineficazes na redução das desigualdades sociais geradas pelo mercado, acabando por reproduzi-las.

O que está em jogo aqui é a busca por novas parcerias e articulações do setor estatal com o setor privado, as quais podem abranger desde a formulação de políticas de criação de emprego (tendo papel de relevo, neste particular, empresas de pequeno e médio porte, à medida em que $94 \%$ das empresas brasileiras têm menos de 70 empregados), até políticas de maior investimento em capital humano ou o compromisso com a efetiva aplicação da legislação 
trabalhista. Tal compromisso implicaria o aumento do poder de fiscalização e de controle do Estado quanto ao cumprimento, pelo setor privado, dos encargos sociais e fiscais. Parte da responsabilidade do setor privado consistiria em participar dos esforços para a superação da pobreza, tanto do lado da oferta (gerando empregos de melhor qualidade), quanto do lado da procura (por intermédio de programas de capacitaçáo e treinamento).

No que diz respeito à relação Estado/sociedade, o grande desafio que se apresenta é ampliar o espaço da sociedade no interior do próprio Estado. Para que políticas públicas de corte social - indispensáveis e urgentes - prosperem, ganhando institucionalidade, continuidade e eficácia, é preciso, antes de tudo, deslocá-las do campo das necessidades e situá-las no campo dos direitos. Superarse-ia, assim, sua conceituação em termos de carências, que implica serem concebidas como políticas assistenciais, prejudicando, em nome de atributos e interesses pontuais, o caráter universal dos direitos.

Segundo essa concepção, embora seja possível identificar focos de concentração de pobreza extrema - como, por exemplo, a pobreza metropolitana (Rio de Janeiro e São Paulo concentram 50\% dos pobres metropolitanos) e a pobreza nordestina (onde áreas urbanas não-metropolitanas e rurais reúnem dois terços dos pobres brasileiros) -, isso não significa que a atenção do poder público deva restringir-se ao alívio da pobreza desses segmentos. Se, para grande parcela dos pobres, principalmente os indigentes, a perspectiva de sair da situação de pobreza a curto prazo, por meio da inserção no mercado de trabalho, é praticamente nula, demandando, portanto, políticas de âmbito local e regional mais focalizadas, isso não pode impedir que assuma caráter igualmente prioritário o resgate do ensino e da escola pública, por exemplo, como parte de uma política universal de formação e de educação tecnológica voltadas para a cidadania.

Nesse ponto, novas parcerias com a sociedade devem ser contempladas na redefiniçáo do Estado. Não se trata de transferir para as comunidades a tarefa de executar programas voltados para o alívio da pobreza de determinados grupos, identificados como mais vulneráveis dentre os vulneráveis. Trata-se, sim, de acolher formas descentralizadas de gestáo da coisa pública, bem como novos mecanismos de co-responsabilidade na definição da própria agenda do Estado. No que diz respeito à criaçáo de canais institucionais de participação na gestão, a experiência brasileira é rica na sua diversidade, a partir, sobretudo, dos preceitos constitucionais de 1988, que determinam a descentralização das políticas sociais e prevêem espaços de participação dos distintos setores organizados da sociedade civil em colegiados das três esferas de poder, e que derivaram, concretamente, nas atividades do Conselho Nacional de Segurança Alimentar, do Conselho Nacional de Seguridade Social, e do Conselho Nacional dos Direitos da Criança e do Adolescente - Conanda. Não resta dúvida, neste particular, de que a descentralização 
favorece a possibilidade de maior controle público sobre o Estado, redefinindose, nesse processo, as responsabilidades do poder central.

Por outro lado, se políticas sociais descentralizadas, eficientes e eficazes, sob controle público, e regidas pela noção de direito tornam-se essenciais - sem excluir (ao contrário, supor) políticas emergenciais e focalizadas sobre grupos identificados como de maior vulnerabilidade - a condição primeira para tanto é a própria reestruturação do Estado, bem como a recuperação de sua capacidade de investimento no campo social.

De fato, a necessidade de promover a descentralização, de criar novas formas de parceria com o setor privado e de abrir espaços de atuação de caráter nãogovernamental, mas de interesse público, não eximem o Estado e a Administração Federal de sua responsabilidade primordial na condução desse processo.

Tendo em vista a magnitude e a urgência de programas redistributivistas para o alívio e a superação da pobreza, bem como a inviabilidade de seu financiamento por intermédio de um sistema basicamente de caráter contributivo, há que se buscar novas formas de solidariedade social. Isso implica a reformulaçáo da lógica de financiamento dessas políticas e sua integração num conjunto coeso, ao lado de novas parcerias do Estado com a sociedade, do setor público com o setor privado. Tais processos ganharão sentido à medida em que seu objetivo fundamental seja converter o espaço público, na sociedade brasileira, em parâmetro básico na busca de maior eficiência e eficácia dos programas de combate à pobreza.

\section{Conclusão}

Os princípios acima mencionados orientam a política social do governo que se inicia, para o qual o enfrentamento da questão social não deverá ter caráter residual e subsidiário; ao contrário, todas as açóes governamentais deverão estar permanentemente informadas pelo compromisso de fạzer face, de forma sistemática, aos problemas sociais do país. Para tanto, terão de ser alcançadas quatro condiçóes prévias: o fortalecimento da democracia, a conquista e a manutenção da eśtabilidade econômica, a recuperação do crescimento sustentado e a reforma do Estado, as quais serão consideradas objetivos prioritários.

Será assim necessário, em primeiro lugar, consolidar e aperfeiçoar o funcionamento das instituiçóes democráticas no país, garantindo e ampliando os direitos da cidadania, fortalecendo os espaços de apresentaçáo de pleitos, de defesa de direitos, de debate, de negociação e de formação de coalizões em defesa do interesse público. Daí a ênfase dada pelo Governo Federal ao diálogo com os 
demais níveis de Governo, com os Poderes Legislativo e Judiciário, com os partidos políticos e com as organizaçóes da sociedade civil.

Em segundo lugar, será imprescindível consolidar o plano de estabilidade econômica - o chamado plano Real -, continuando a luta contra a inflação que corrói os salários, aumentando a carestia; dificulta o cálculo econômico de médio e longo prazos, prejudicando os investimentos produtivos; incentiva a prevalência de interesses estreitos e imediatistas, prejudicando os acordos de longa duraçăo; esgarça e corrói o tecido social, debilitando a confiança nas instituições e instala um clima permanente de avidez, insegurança e violência, desorganizando as famílias e as comunidades. Essas situaçóes, como se sabe, atingem mais duramente os segmentos mais pobres da população, privados dos meios para se defender da inflação elevada e da instabilidade crônica.

Em terceiro lugar, impóe-se a retomada do crescimento econômico sobre novas bases, quer do ponto de vista tecnológico, quer do ponto de vista organizacional, quer do ponto de vista da distribuição de tarefas entre o setor público e o setor privado, quer, ainda, do ponto de vista das relaçóes da economia brasileira com a economia mundial. Será preciso consolidar uma economia mais competitiva e menos protegida, menos dilapiladora do meio ambiente e dos recursos naturais não-renováveis e, sobretudo, que propicie mais geração de empregos, de melhor qualidade, bem como melhor distribuição de renda entre capital e trabalho, em favor deste último.

O Estado brasileiro - tributário do padrão anterior de crescimento, no qual desempenhou função estratégica - hoje se mostra anacrônico, parcialmente falido e, em conseqüência, desaparelhado para as importantes tarefas de coordenação e direção que lhe cabem desempenhar na transformação do país, ou mesmo para a prestação mais abrangente e descentralizada de serviços públicos básicos de melhor qualidade. A quarta prioridade seria, portanto, realizar uma reforma profunda do Estado brasileiro, tornando-o mais ágil e eficaz. Cumpre lembrar que passo preliminar para a formulação de um projeto de desenvolvimento é a recuperaçáo das fundações e institutos públicos responsáveis pela coleta, sistematização, análise e divulgaçáo dos dados sócio-econômicos acerca da realidade brasileira.

$\mathrm{Na}$ área social, serão contempladas mudanças na direção de maior controle público sobre a prestação de serviços, de número maior de atividades em parceria com a sociedade civil, e de crescente descentralização, capaz de retirar do nível federal as atividades operacionais de execução, com o objetivo de melhorar a capacidade de coordenação e a funç̧ão redistributiva desse nível de governo. Contemplar-se-á, também, melhor qualificação e melhores salários para os profissionais do serviço públi$\mathrm{co}$, principalmente aqueles dedicados ao ensino fundamental $\mathrm{e}$ aos serviços de saúde, tão logo o saneamento fiscal e a reforma tributária assim o permitam. 
Por indispensáveis que sejam as transformações a que se acaba de aludir, será necessário desenvolver, concomitantemente, um conjunto de açōes voltadas específica e diretamente para o enfrentamento da questão social no Brasil. Dessa forma, além da ênfase a ser dada à urgente necessidade de racionalizar e tornar mais eficiente e eficaz o gasto público, importância central será concedida a cinco metas prioritárias: agricultura, educação, emprego, saúde e segurança.

Com relação ao gasto público federal na área social, será dada prioridade a sua melhor utilização, evitando-se o desperdício, multiplicando-se os esforços de maior controle público sobre seu destino, corrigindo-se o padrão de financiamento, hoje pró-cíclico e socialmente regressivo, e modificando-se a estrutura dos benefícios de modo a aumentar seu impacto redistributivo. Com essas mudanças de padrão, o Governo espera que o gasto social total brasileiro tenha resultados bem mais satisfatórios para a população carente.

Já as cinco metas prioritárias indicam clara intenção de enfrentar a questão social com determinação, tanto no campo como na cidade, por intermédio de um conjunto diferenciado de programas e açôes.

A atenção dada à agricultura privilegiará a criação de empregos, a produção mais abundante e barata de alimentos, a assistência técnica e creditícia ao pequeno e médio produtor $\mathrm{e} o$ assentamento de famílias de trabalhadores rurais sem terra, além de projetos de eletrificação rural e universalização de fato dos benefícios básicos da previdência social ao homem do campo.

No que tange à educação, será dada ênfase aos seguintes objetivos: redução das elevadas taxas de repetência e melhoria substancial da qualidade do ensino de primeiro grau (o qual terá caráter prioritário), por intermédio da valorização da escola e da garantia de merenda e material escolar básico para cada aluno das escolas públicas; preparação cuidadosa da futura expansão do segundo grau, o qual terá caráter mais prático e experimental; reformulaçáo do ensino técnico e profissional, de forma a adequá-lo às novas exigências do mundo do trabalho; diversificação e melhor controle do financiamento e gestáo do ensino superior, por meio de sua progressiva autonomização e de uma política socialmente mais justa'de acesso a instituições de ensino superior de caráter público. Tais políticas serão implementadas em colaboração com os estados, os municípios e as mais diversas organizações da sociedade civil (empresas, organizações comunitárias, sindicatos etc).

Em que pese a recente e pronunciada queda da natalidade no país, o problema da oferta de empregos será ainda crucial nos próximos quinze anos. Por isso, a geração de mais e melhores postos de trabalho continuará sendo estratégica para o Brasil. Infelizmente, as transformaçóes organizacionais e tecnológicas em 
curso parecem pouco dinâmicas em termos de criação de empregos, ao mesmo tempo em que o mundo moderno exige uma força de trabalho crescentemente qualificada, versátil e flexível. Por todas essas razóes, o Governo brasileiro, em seus diferentes níveis e através de múltiplas parcerias, deverá dedicar atenção especial a um conjunto de programas voltados para o incentivo à geraçáo de empregos, para a qualificação e o retreinamento da mão-de-obra, e para a melhoria das condições de segurança no trabalho. Além disso, numa economia necessariamente mais vulnerável à competição e às variações cíclicas, será necessário aprimorar os mecanismos do seguro-desemprego.

Nesse âmbito, será dada atenção especial à pequena e à média empresas e aos setores mais dinâmicos em termos de emprego, como certos segmentos da agricultura, dos serviços sociais e pessoais, e às atividades de lazer, esporte e turismo. Será também considerada a modernização das relaçóes de trabalho, a partir da diminuiçáo do chamado custo Brasil - mediante a redução dos encargos trabathistas e a dinamização de formas mais contemporâneas de proteção do trabalhador (reformulação da Justiça do Trabalho, contrato coletivo, câmaras setoriais, participaçáo nos lucros etc.).

$\mathrm{Na}$ área de saúde, o primeiro passo do Governo Federal será equacionar o financiamento do setor, por intermédio da garantia de recursos estáveis. Esperase que a estabilidade econômica, a retomada do crescimento e medidas na área fiscal e tributária permitam elevar esses recursos, a médio prazo. O segundo passo consiste na implementação efetiva do SUS (Sistema Unificado de Saúde), reorientando-se a política de assistência para a promoção da saúde e a prevenção da doença. Como terceiro passo, buscar-se-á crescente colaboração dos estados e dos municípios na oferta dos serviços e no controle de sua execução em nível local, enfatizando-se a participação comunitária e definindo-se com clareza as responsabilidades de cada um dos níveis de governo. Com esses recursos, a reorientação da política de assistência e a adoção de uma política de eliminaçăo dos desperdícios e racionalizaçáo dos gastos, o Governo espera poder proporcionar assistência básica ao conjunto da população brasileira.

No que tange à defesa da cidadania, justiça e segurança pública, os objetivos centrais do Governo são a garantia do funcionamento eficaz da justiça - especialmente para os grupos de menor renda -; a eliminação da impunidade; o combate ao crime organizado e ao tráfico de drogas; e a luta contra a corrupçáo, a sonegação fiscal e os crimes de colarinho branco. Para isso, será necessária a reestruturação de alguns órgãos federais, uma estreita articulação entre o Poder Executivo e o Poder Judiciário e sistemática colaboração entre a União, os estados e os municípios.

O Governo Federal deverá enfatizar seu papel coordenador e normatizador na maioria dos programas que se acaba de delinear, ficando a ação executiva a 
cargo dos estados e municípios. O princípio da descentralização, entretanto, não deve eximir a esfera federal de seu papel redistribuidor de recursos, com vistas a promover maior eqüidade entre os diferentes segmentos da população e entre as diferentes regióes do país. Há, também, consciência de que o impacto positivo dessas ações dependerá, como já se assinalou, da retomada do crescimento econômico, o que significa que seus efeitos se farăo sentir a médio e longo prazos.

Náo se ignora, contudo, que dezenas de milhões de brasileiros vivem em condições cuja precariedade não lhes permite continuar aguardando os benefícios que adviráo de uma nova estratégia de desenvolvimento, capaz de conciliar a modernização da economia com a redução das disparidades sociais e regionais, bem como da reformulação, a médio prazo, da política social do país nas áreas de educação, emprego, saúde, segurança e justiça. São necessárias, portanto, ações que possam se traduzir em benefícios imediatos e diretos para a populaçáo brasileira mais carente e necessitada.

Com esse objetivo, e com o antecedente da bem-sucedida experiência brasileira de mobilização para o combate à fome organizada pela $A_{f} \tilde{a} o$ da Cidadania Contra a Fome e a Miséria e pela a Vida, com o apoio do Conselho Nacional de Seguranfa Alimentar (Consea), foi criado o Programa de Combate à Fome e à Pobreza Comunidade Solidária, que sistematiza e amplia a iniciativa anterior.

Inspirado em modelos que defendem o acesso público e universal a direitos sociais básicos, e sem ignorar que pobreza e fome só podem ser erradicadas mediante a retomada sustentada do crescimento econômico, o Programa reflete a prioridade atribuída pelo Governo brasileiro à melhoria das condiçôes de vida desses cidadãos.

Tendo como horizonte de médio e longo prazos a firme determinação de inserir o tema do desenvolvimento social na pauta das prioridades que irão determinar as estratégias de desenvolvimento nacional neste final de década, o Programa reconhece, entretanto, que a urgência do problema requer providências de impacto imediato. Trata-se, assim, de selecionar entre as açōes do Governo Federal, aquelas que, se gerenciadas de forma mais eficiente e eficaz, poderão contribuir efetivamente para a promoção de melhoria da condição social dos segmentos mais pobres da população.

As açōes que compóem o Programa não se limitam ao campo de atuação que convencionalmente demarca o espaço das chamadas políticas sociais. Dentro de uma concepçáo que articula desenvolvimento econômico e desenvolvimento social, o combate à fome e à pobreza deve abranger a totalidade das questóes abordadas nos diferentes segmentos da Administração Pública. 
O princípio básico do Programa é a participação e parceria solidária da comunidade e do governo, em suas diferentes esferas, na busca de soluçóes mais adequadas, em cada caso, para a melhoria das condiçóes de vida da população. A descentralização, a integração dos esforços dos três níveis de governo, a convergência das ações governamentais, a eficiência na gestão, a eficácia do atendimento e a equiidade nos resultados são as diretrizes a serem seguidas.

O Governo Federal apoiará, estimulará, concederá assistência financeira e mobilizará recursos adicionais para ampliar o alcance do Programa, atuando em estreita sintonia com os governos estaduais e municipais. A estes competirá a iniciativa de um trabalho conjunto com as comunidades a serem atendidas, com as organizaçóes não governamentais que atuam na área e com os Comitếs da Af̧ão da Cidadania contra a Fome e a Miséria e Pela Vida, visando à seleção das açóes prioritárias em cada localidade, à identificação das melhores alternativas para enfrentar o problema em cada regiáo e à garantia das contrapartidas de recursos humanos, materiais e financeiros que, somados à parcela a cargo do Governo Federal, permitirão atender as respectivas necessidades.

A oferta dos serviços sociais não deverá, nesse contexto, ser monopolizada por organizações estatais. Sempre que possível, serão incentivadas e apoiadas açốes realizadas autonomamente pelas organizaçóes comunitárias e as diversas formas de parceria entre o governo e o setor privado. Do mesmo modo, serão realizadas açôes focalizadas, voltadas para o atendimento prioritário de regióes e segmentos sociais em situaçáo de extrema pobreza, desvantagem ou risco.

Os componentes do Programa classificam-se em cinco categorias - Alimentação e Nutrição, Serviços Urbanos Básicos, Desenvolvimento Rural, Geração de Emprego e Renda e Defesa dos Direitos e Promoção Social - em funçáo da natureza das atividades exercidas. Essas açóes compreendem cerca de 14 programas específicos, distribuídos pelos diferentes ministérios da Administração Federal, com recursos da ordem de quatro bilhões de dólares, contemplados no orçamento federal de 1995.

O acesso a recursos do Programa será possível por meio da apresentação de propostas elaboradas em nível local (municípios e microrregióes), com a participação efetiva das prefeituras, dos governos estaduais, das universidades, das organizaçóes da sociedade civil e da comunidade. Tal colaboração terá, entre outros objetivos, os de mobilizar recursos complementares para ampliar o escopo dos projetos e de organizar formas participativas de controle e gestão da execução do Programa. Caberá aos órgãos técnicos do Governo Federal avaliar se as propostas atendem às prioridades do Programa, analisar sua viabilidade e zelar pela correta utilização dos recursos. Todas as demais atividades deverão ocorrer em ní- 
ve1s regional e local, devendo a gestão das ações e dos recursos ser atribuída à comunidade, nos casos em que houver condiçóes para tanto.

O processo de enquadramento e avaliação das propostas obedecerá a critérios objetivos, entre os quais se destacam sua localização geográfica nas áreas de maior concentração relativa de pobreza; o grau de integração existente entre as diferentes açōes propostas, tendo em vista combater as causas básicas da pobreza; o impacto esperado das ações na atenuação dos efeitos da pobreza; a focalização das açốes propostas nos grupos sociais de fato mais desfavorecidos; e o comprometimento efetivo de diferentes segmentos e organizaçóes, inclusive por meio da mobilização de recursos financeiros, humanos e organizacionais adicionais.

O Governo Federal reconhece, entretanto, que muitas áreas pobres do país não possuem as condições mínimas necessárias para a execução dessas propostas em tempo hábil, preenchendo os requisitos técnicos exigidos. Para não prejudicar essas áreas, o Governo Federal adotará uma postura pró-ativa, selecionando municípios de acordo com critérios técnicos e proporcionando a eles a assistência necessária.

Ao contrário do que ocorreu em outros países, o Governo Federal não pretende criar estruturas paralelas para desenvolver esse Programa. O Programa Comunidade Solidária será executado por intermédio dos órgãos existentes, criando-se tão somente uma Secretaria Executiva junto ao Gabinete Civil da Presidência da República - o que lhe confere relevância e prioridade - a qual coordenará as ações no âmbito da administração federal.

Com o Programa Comunidade Solidária, o Governo Federal pretende contribuir para que se realize uma grande mobilização nacional para enfrentar, no curto prazo, as situaçóes mais prementes de fome, desemprego e miséria.

Com o objetivo de conferir maior visibilidade e transparência ao Programa Comunidade Solidária, bem como contribuir de forma ativa para a mobilização dos outros níveis de governo (estados e municípios), da sociedade civil e da comunidade, transformar-se-á o Consea em um Conselho da Comunidade Solidária, vinculado à Presidência da República e integrado pelos Ministros de Estado das áreas mais diretamente envolvidas com o Programa, além de personalidades de diferentes segmentos da sociedade civil, escolhidas pelo Presidente da República, e reconhecidas por seu papel na luta pela melhoria das condiçóes de vida da população e pela defesa da cidadania.

Caberá a esse Conselho - que tem caráter consultivo e será presidido por pessoa de reconhecido mérito e envolvimento nas questóes sociais -, constituir-se 
em instrumento de mobilização da sociedade e de divulgação nacional e internacional do Programa, debater questōes relacionadas às açôes de combate à fome e à miséria, encaminhar propostas de políticas para o setor ao Presidente da República e acompanhar a ação do Estado nessa área.

Em suma, embora o Programa Comunidade Solidária constitua o eixo em torno do qual se articulam programas e políticas sociais específicos, a busca por justiça social constitui objetivo prioritário a orientar todas as políticas de governo, as quais serão implementadas em processo de constante diálogo com a sociedade civil.

\section{Referências bibliográficas}

ALBUQUERQUE, R. C. Estratégia de desenvolvimento e combate à pobreza. Paper apresentado em Seminário promovido pelo Ministério das Relações Exteriores. São Paulo, set. 1994.

AMADEO, E.J. \& CAMARGO, J. M. Instituicôes e mercado de trabalho no Brasil. Rio de Janeiro, s/d. [mimeo].

BANCO MUNDIAL. Brazil: public spending on social programs: issues and options. v. I, maio, 1988.

BONELLI, R. \& RAMOS, L. Distribuigão de renda no Brasil: apaliação das tendências de longo prazo e mudanfas na desigualdade desde meados dos anos 70 . Texto para Discussão n. 288. Ipea, jan. 1993.

CAMARGO, J. M. Desigualdade e pobreza no Brasil - flexibilidade, produtividade e instituiçōes. In: Fórum: Brasil 1995. Rio de Janeiro, nov. 1994.

CORREA, S. Desenvolvimento, cidadania e participação: a experiência brasileira. Paper apresentado em Seminário promovido pelo Ministério das Relaçōes Exteriores. Recife, out. 1994.

DAIN, S. Educaç̃̃o e sistemas de proteçāo social do trabalho. Paper apresentado em Seminário promovido pelo Ministério das Relações Exteriores. Rio de Janeiro, dez. 1994.

DESEP/CUT. Indicadores Desep/94. São Paulo.

DIEESE. Anudrio dos Trabalhadores 1993. São Paulo.

FUNDAÇÃO OSWALDO CRUZ. Dados n. 16. Radis (Reunião, Análise e Difusão de Informação sobre Saúde). Rio de Janeiro, jul./ago. 1993.

HICKS, N. L. Poverty and social development in Latin America. Latin America and Caribbean Region, Banco Mundial, dez. 1992. 
IBGE. Anuário Estatístico do Brasil 1993.

. Indicadores de condiçốes de vida. In: Boletim Informativo n. 1, ago. 1993.

- Indicadores sócio-demográficos. In: Censo Demográfico 1991.

- Crianças e adolescentes, indicadores sociais. In: Censo Demográfico 1991.

- Mapa do mercado de trabalbo no Brasil, n. 1, 1994.

JATOBÁ, J. Desigualdade e pobreza no Brasil, estrutura e dịnâmica do mercado de trabalho brasileiro. In: Fórum: Brasil, 1995. Rio de Janeiro, nov. 1994.

- Encargos sociais, custos da mão-de-obra e flexibilidade do mercado de trabalho no Brasil: Seminário sobre Regulação do Mercado de Trabalho no Brasil. Belo Horizonte, mar. 1994.

LAVINAS, L. · Desigualdade e pobreza no Brasil - desigualdades regionais: como priorizar quem mais precisa? Fórum Brasil, 1995. Rio de Janeiro, nov. 1994.

LOPES, J. S. L. Caracterização do mercado de trabalho, economia rural, informal, emprego urbano e rural. Paper apresentado em Seminário promovido pelo Ministério das Relações Exteriores. Rio de Janeiro, dez. 1994.

LOPES, J. B. Politica social: subsidios estatísticos sobre a pobreza e acesso a programas sociais no Brasil. Paper apresentado em Seminário promovido pelo Ministério das Relações Exteriores. São Paulo, set. 1994.

MEDEIROS, C. et alii. Relações de trabalho, educação e mecanismos de proteção social. Série Seminários, n. 15/93, Ipea, jul. 1993.

OLIVEIRA, F. O flanco aberto: Vulnerabilidade social e carência de direitos. Paper apresentado em Seminário promovido pelo Ministério das Relaçóes Exteriores. Recife, out. 1994.

OLIVEIRA, J. S. (org.). O traço da desigualdade social no Brasil. IBGE, nov. 1993.

PELIANO, A. M. T. M. (coord.). O mapa da fome II: informaçóes sobre a indigência por municípios da Federação. In: Documento de política, n. 15. Ipea, abr. 1993.

- O mapa da fome: subsídios à formulação de uma política de segurança alimentar. In: Documento de política, n. 14. Ipea, mar. 1993.

PNUD. Relatório de Desenvolvimento Humano 1994.

REIS VELLOSO, J. P. Modernidade e pobreza: a construção da modernidade econômico-social. In: VI Fórum nacional. Rio de Janeiro, abr. 1994. 
ROCHA, S. Desigualdade e pobreza no Brasil, cinco questóes acerca de pobreza no Brasil. In: Fórum: Brasil, 1995. Rio de Janeiro, nov. 1994.

[mimeo].

Governabilidade e pobreza: o desafio de nimeros. Rio de Janeiro, jun. 1994

SANTOS, W. G. (org.). Que Brasil é este? São Paulo, Vértice, 1990.

SMITH, R. \& OLIVEIRA, A. A. Brasil: integração social e equalização de oportunidades? Paper apresentado em Seminário promovido pelo Ministério das Relaçóes Exteriores. Recife, out. 1994.

URANI, A. Ajuste macroeconômico e flexibilidade do mercado de trabalho no Brasil-19811992, nov., 1994.

Crescimento económico e geração de emprego e renda no Brasil. Paper apresentado em Seminário promovido pelo Ministério das Relaçóes Exteriores. Rio de Janeiro, dez. 1994.

\section{Resumo}

O relatório nacional brasileiro, elaborado como parte do processo de preparação da participação brasileira na Cúpula Mundial para o Desenvolvimento Social, busca traçar um quadro da situação do Brasil em relação aos três temas centrais do evento: alívio e redução da pobreza, expansão do emprego produtivo e integração social. Com o objetivo de qualificar a peculiaridade dos desafios sociais com os quais o Brasil se defronta, a primeira parte consiste de um quadro abrangente, onde estão expostos os dados gerais mais relevantes. A segunda parte, de caráter conceitual, explora a relação à dicotomia desenvolvimento econômico/desenvolvimento social, políticas econômicas/políticas sociais. Passa-se, então, à parte do relatório mais diretamente ligada aos temas centrais da Cúpula. O capítulo sobre pobreza busca sistematizar algumas das principais características desse fenômeno no Brasil; em "Emprego e mercado de trabalho" examinam-se questóes como a baixa taxa de desemprego aberto do mercado brasileiro e sua relação com a má qualidade dos postos de trabalho existentes; finalmente, "Integração social e políticas sociais" salienta a necessidade de novas formas de solidariedade social, o que implicaria a reformulação da lógica de financiamento das políticas sociais e sua integração num conjunto coeso, ao lado de novas parcerias do Estado com a sociedade e do setor público com o setor privado. À guisa de conclusão, alinham-se as principais diretrizes do Governo Federal para o período 1995-1999. Depois de enfatizar a necessidade de que quatro condições prévias - fortalecimento da democracia, manutenção da estabilidade econômica, recuperação do crescimento sustentado e reforma do Estado - sejam alcançadas, identificam-se cinco metas prioritárias na área social: agricultura, educação, emprego, saúde e segurança. O relatório termina com breve esboço da estrutura do Programa Comunidade Solidária e a advertência de que este náo esgota a política social do Governo brasileiro, a qual constitui objetivo prioritário a orientar políticas em todas as áreas de atuação. 


\begin{abstract}
The Brazilian National report was elaborated as part of the process of preparations for the Brazilian participation in the World Summit for Social Development. It endevors to delineate a picture of Brazil in relation to the three central themes of the event, namely the relief and reduction of poverty, the expansion of productive employment, and social integration. The first part, aiming to identify the peculiarities of the social chalenges Brazil is faced with, consists of as comprehensive survey of the more relevant general data. The second part, of a conceptual character, inquires into the relationship between social development and justice for all, particularly in the area where economic/social development and economic/social policy diverge. The Report then goes on to the part more directly linked to the central theme of othe Summit. The chapter on poverty endevors to describe some of the main characteristics of this phenomenon in Brazil. Under "Employment and Labor Market", topics such as the low rate of usable unemployment in the Brazilian market place and its relation to the poor quality of available jobs are examined. Finally "Social Integration and social Policy" stressesd the necessity for new structures for social solidarity, which would imply the reorganization of the logistics of financing and its integration in a cohesive plan, together with new partnerships of the State with Society, and of the public with the private sector. By way of conclusion, the main directives of the Federal Government for 1995-1999 are drawn. It emphasizes the need to reach four fundamental conditions, namely the strengthning of democracy, the maintaining of economic stability, the recuperation of sustained growth, and the remodeling of the State.To achieve this, five priority targets in the social area are identified: agriculture, education, employment, health, and security. The Report ends with a brief outline of the structure of the Solidarity Community Program and calls attention to the fact that the program is not the sole social policiy of the Brazilian Government, but is rather the guideline for programs in all areas of government.
\end{abstract}

\title{
Relatorias:
}

Relatora geral: Amélia Cohn.

Relatora do seminário sobre Desenvolvimento social e pobreza: Elisa Lustosa Caillaux.

Relator do seminário sobre Integração social: desafio dos anos 90: Sebastião Jorge Jatobá Bezerra dos Santos.

Relator do seminário sobre Desenvolvimento social e trabalbo: Luis Antônio Machado da Silva.

Debatedores:

Seminário Desenvolvimento social e pobreza: Sônia Maria Rodrigues Rocha.

Seminário Integração social: desafio dos anos 90: Tânia Souto Bacelar de Araújo.

Consultorias:

Seminário Desenvolvimento social e pobreza

- Tema Estado, sociedade e pobreza: politicas, aföes e seu alcance: Vilmar Evangelista Faria.

- Tema Caracterização da pobreza: urbana e rural: Juarez Rubens Brandão Lopes (urbana) e Ronaldo Coutinho Garcia (rural). 
- Tema Estratégias de desenvolvimento na superafão da pobreza: Roberto Cavalcanti de Albuquerque.

Seminário Integrafāo social: desafio dos anos 90

- Tema Cidadania, participação e desenvolvimento: Sônia Onufer Correa.

- Tema Integrafão de grupos socialmente pulnerápeis: Francisco Maria Cavalcanti de Oliveira.

- Tema Equalizañão de oportunidades: Roberto Smith.

Seminário Desenvolvimento social e trabalho

- Tema Caracterizafão do mercado de trabalho: economia formal, informal, emprego Urbano e Rural: José Sérgio Leite Lopes.

- Tema Educação e sistemas de proteção social do trabalho: Sulamis Dain.

- Tema Crescimento económico, gerafẵo de emprego e renda: André Urani 
Tabela 1

Dados de caracterização geral, segundo as Grandes Regiões

Brasil, 1990

\begin{tabular}{lccrrr}
\hline Região & $\begin{array}{c}\text { Extensão territorial } \\
(\%)\end{array}$ & $\begin{array}{c}\text { População } \\
(\%)\end{array}$ & $\begin{array}{r}\text { Habitante/km² } \\
(\%)\end{array}$ & $\begin{array}{r}\text { PIB 1985* } \\
\%\end{array}$ & $\begin{array}{r}\text { PIB 1992** } \\
\% \text { estimada }\end{array}$ \\
\hline Norte & 45,26 & 5,90 & 2,39 & 4,35 & 5,53 \\
Sudeste & 10,85 & 43,50 & 73,61 & 59,40 & 56,18 \\
Nordeste & 18,27 & 28,50 & 29,07 & 13,83 & 15,86 \\
Centro-Oeste & 18,86 & 6,80 & 6,62 & 5,33 & 5,69 \\
Sul & 6,76 & 15,05 & 41,28 & 17,09 & 16,74 \\
\hline
\end{tabular}

* Ibge - Contas Nacionais - FGV

** Estimativa - FGV/Desep, 1994.

Fonte; Ibge - Dados Pnad, 1990.

Tabela 2

Distribuição da população, por sexo, segundo os grupos de idade Brasil, 1940-1991

\begin{tabular}{|c|c|c|c|c|c|c|}
\hline \multirow[t]{2}{*}{ Grupos de idade } & \multicolumn{6}{|c|}{ Distribuição da população } \\
\hline & 1940 & 1950 & 1960 & 1970 & 1980 & 1991(1) \\
\hline \multicolumn{7}{|c|}{ Total } \\
\hline \multicolumn{7}{|l|}{ População absoluta } \\
\hline (1000 Hab.) & $41.236,3$ & $51.944,4$ & $70.191,4$ & $93.139,0$ & $119.002,7$ & $147.053,9$ \\
\hline População relativa(\%) & 100,0 & 100,0 & 100,0 & 100,0 & 100,0 & 100,0 \\
\hline 0 a 4 anos & 15,6 & 16,1 & 16,0 & 14,8 & 13,8 & 11,2 \\
\hline 5 a 9 anos & 14,0 & 13,5 & 14,5 & 14,4 & 12,4 & 11,9 \\
\hline 10 a 14 anos & 12,9 & 12,1 & 12,2 & 12,7 & 12,0 & 11,6 \\
\hline 15 a 19 anos & 10,8 & 10,6 & 10,2 & 11,0 & 11,4 & 10,2 \\
\hline 20 a 24 anos & 9,3 & 9,6 & 8,9 & 8,9 & 9,7 & 9,2 \\
\hline 25 a 29 anos & 8,1 & 8,0 & 7,5 & 7,0 & 7,9 & 8,6 \\
\hline 30 a 34 anos & 6,3 & 6,2 & 6,4 & 6,1 & 6,6 & 7,5 \\
\hline 35 a 39 anos & 5,6 & 5,9 & 5,6 & 5,5 & 5,3 & 6,4 \\
\hline 40 a 44 anos & 4,7 & 4,6 & 4,6 & 4,9 & 4,8 & 5,3 \\
\hline 45 a 49 anos & 3,6 & 3,8 & 3,9 & 3,8 & 3,9 & 4,2 \\
\hline 50 a 54 anos & 3,0 & 3,0 & 3,1 & 3,2 & 3,5 & 3,5 \\
\hline 55 a 59 anos & 1,9 & 2,1 & 2,3 & 2,5 & 2,6 & 2,9 \\
\hline 60 a 64 anos & 1,7 & 1,8 & 2,0 & 1,9 & 2,1 & 2,5 \\
\hline 65 a 69 anos & 0,9 & 1,0 & 1,1 & 1,3 & 1,7 & 1,9 \\
\hline 70 a 74 anos & 0,7 & 0,7 & 0,8 & 0,9 & 1,1 & 1,3 \\
\hline 75 a 79 anos & 0,4 & 0,4 & 0,4 & 0,4 & 0,7 & 0,9 \\
\hline 80 anos ou mais & 0,4 & 0,4 & 0,4 & 0,5 & 0,5 & 0,8 \\
\hline Idade ignorada & 0,1 & 0,2 & 0,1 & 0,2 & 0,1 & 0,2 \\
\hline
\end{tabular}


Tabela 2 (continuação)

Distribuição da população, por sexo, segundo os grupos de idade

Brasil, 1940-1991

\begin{tabular}{|c|c|c|c|c|c|c|}
\hline \multirow[t]{2}{*}{ Grupos de idade } & \multicolumn{6}{|c|}{ Distribuição da população } \\
\hline & 1940 & 1950 & 1960 & 1970 & 1980 & 1991(1) \\
\hline $\begin{array}{l}\text { População absoluta } \\
\text { (1000 Hab.) } \\
\text { População relativa(\%) } \\
0 \text { a } 4 \text { anos } \\
5 \text { a } 9 \text { anos } \\
10 \text { a } 14 \text { anos } \\
15 \text { a } 19 \text { anos } \\
20 \text { a } 24 \text { anos } \\
25 \text { a } 29 \text { anos } \\
30 \text { a } 34 \text { anos } \\
35 \text { a } 39 \text { anos } \\
40 \text { a } 44 \text { anos } \\
45 \text { a } 49 \text { anos } \\
50 \text { a } 54 \text { anos } \\
55 \text { a } 59 \text { anos } \\
60 \text { a } 64 \text { anos } \\
65 \text { a } 69 \text { anos } \\
70 \text { a } 74 \text { anos } \\
75 \text { a } 79 \text { anos } \\
80 \text { anos ou mais } \\
\text { ldade ignorada }\end{array}$ & $\begin{array}{r}20.614,10 \\
100,0 \\
15,8 \\
14,2 \\
13,0 \\
10,5 \\
8,9 \\
8,0 \\
6,3 \\
5,7 \\
4,9 \\
3,8 \\
3,1 \\
2,0 \\
1,6 \\
0,9 \\
0,6 \\
0,3 \\
0,3 \\
0,1\end{array}$ & $\begin{array}{r}25.885,00 \\
100,0 \\
16,4 \\
13,8 \\
12,2 \\
10,2 \\
9,2 \\
7,9 \\
6,3 \\
5,9 \\
4,8 \\
3,9 \\
3,1 \\
2,1 \\
1,8 \\
1,0 \\
0,6 \\
0,3 \\
0,3 \\
0,2\end{array}$ & $\begin{array}{r}35,059,60 \\
100,0 \\
16,2 \\
14,8 \\
12,3 \\
9,9 \\
8,5 \\
7,3 \\
6,4 \\
5,6 \\
4,7 \\
4,0 \\
3,2 \\
2,3 \\
2,1 \\
1,1 \\
0,8 \\
0,4 \\
0,3 \\
0,1\end{array}$ & $\begin{array}{r}46.331,30 \\
100,0 \\
15,0 \\
14,7 \\
12,8 \\
10,8 \\
8,7 \\
6,9 \\
6,1 \\
5,4 \\
4,9 \\
3,9 \\
3,2 \\
2,5 \\
2,0 \\
1,3 \\
0,8 \\
0,4 \\
0,4 \\
0,2\end{array}$ & $\begin{array}{r}59.123,40 \\
100,0 \\
14,1 \\
12,7 \\
12,1 \\
11,3 \\
9,6 \\
7,9 \\
6,4 \\
5,3 \\
4,8 \\
3,9 \\
3,4 \\
2,6 \\
2,0 \\
1,7 \\
1,1 \\
0,6 \\
0,4 \\
0,1\end{array}$ & $\begin{array}{r}72.604,00 \\
100,0 \\
11,5 \\
12,2 \\
11,8 \\
10,3 \\
9,2 \\
8,5 \\
7,4 \\
6,3 \\
5,3 \\
4,1 \\
3,5 \\
2,8 \\
2,4 \\
1,8 \\
1,2 \\
0,8 \\
0,6 \\
0,2\end{array}$ \\
\hline \multicolumn{7}{|c|}{ Mulheres } \\
\hline $\begin{array}{l}\text { População absoluta } \\
\text { (1000 Hab.) } \\
\text { População relativa(\%) } \\
0 \text { a } 4 \text { anos } \\
5 \text { a } 9 \text { anos } \\
10 \text { a } 14 \text { anos } \\
15 \text { a } 19 \text { anos } \\
20 \text { a } 24 \text { anos } \\
25 \text { a } 29 \text { anos } \\
30 \text { a } 34 \text { anos } \\
35 \text { a } 39 \text { anos } \\
40 \text { a } 44 \text { anos } \\
45 \text { a } 49 \text { anos } \\
50 \text { a } 54 \text { anos } \\
55 \text { a } 59 \text { anos } \\
60 \text { a } 64 \text { anos } \\
65 \text { a } 69 \text { anos } \\
70 \text { a } 74 \text { anos } \\
75 \text { a } 79 \text { anos } \\
80 \text { anos ou mais } \\
\text { Idade ignorada }\end{array}$ & $\begin{array}{r}20.622,20 \\
100,0 \\
15,4 \\
13,8 \\
12,8 \\
11,1 \\
9,6 \\
8,3 \\
6,2 \\
5,6 \\
4,6 \\
3,4 \\
2,9 \\
1,8 \\
1,7 \\
1,0 \\
0,8 \\
0,4 \\
0,5 \\
0,1\end{array}$ & $\begin{array}{r}26,059,40 \\
100,0 \\
15,9 \\
13,2 \\
12,1 \\
11,0 \\
10,0 \\
8,1 \\
6,2 \\
5,8 \\
4,4 \\
3,7 \\
3,0 \\
2,0 \\
1,8 \\
1,0 \\
0,7 \\
0,4 \\
0,5 \\
0,2\end{array}$ & $\begin{array}{r}35.131,80 \\
100,0 \\
15,7 \\
14,2 \\
12,1 \\
10,6 \\
9,2 \\
7,7 \\
6,5 \\
5,7 \\
4,5 \\
3,8 \\
3,0 \\
2,2 \\
1,9 \\
1,1 \\
0,8 \\
0,4 \\
0,5 \\
0,1\end{array}$ & $\begin{array}{r}46.807,70 \\
100,0 \\
14,6 \\
14,2 \\
12,7 \\
11,2 \\
9,1 \\
7,1 \\
6,1 \\
5,5 \\
4,8 \\
3,8 \\
3,1 \\
2,4 \\
1,9 \\
1,3 \\
0,9 \\
0,5 \\
0,6 \\
0,2\end{array}$ & $\begin{array}{r}59.879,30 \\
100,0 \\
13,5 \\
12,2 \\
11,9 \\
11,5 \\
9,7 \\
8,0 \\
6,5 \\
5,4 \\
4,8 \\
3,9 \\
3,5 \\
2,6 \\
2,1 \\
1,7 \\
1,2 \\
0,8 \\
0,6 \\
0,1\end{array}$ & $\begin{array}{r}74.449,90 \\
100,0 \\
10,9 \\
11,6 \\
11,4 \\
10,1 \\
9,2 \\
8,7 \\
7,6 \\
6,5 \\
5,3 \\
4,2 \\
3,5 \\
3,0 \\
2,6 \\
2,0 \\
1,4 \\
1,0 \\
0,9 \\
0,2\end{array}$ \\
\hline
\end{tabular}

Nota: Para 1940, 1950 e 1960 considerou-se a população presente e para 1970, 1980 e 1991 a população residente.

(1) Apuração preliminar da pesquisa do universo do Censo Demográfico de 1991.

Fonte; Ibge, Diretoria de Pesquisas, Departamento de População, Censo Demográfico. 
Tabela 3

Taxa de analfabetismo das pessoas de 7 anos ou mais de idade, por Grandes Regiões, segundo a cor e grupos de idade Brasil, 1990

Taxa de analfabetismo das pessoas de 7 anos ou mais de idade (\%)

Cor e grupos de idade

Brasil (1)

Grandes Regiões

Norte (2) Nordeste Sudeste Sul .Centro-

Oeste

\begin{tabular}{lrrrrrr}
\hline Total (4) (5) & 19,6 & 14,2 & 39,1 & 11,2 & 11 & 17,6 \\
7 a 9 anos (4) & 38,9 & 40,5 & 68,3 & 22,4 & 17,8 & 37,9 \\
10 anos ou mais (4) (5) & 17,8 & 11,3 & 35,8 & 10,2 & 10,4 & 15,6 \\
10 a 14 anos (4) & 14,4 & 10,4 & 33 & 4,2 & 3 & 10,7 \\
15 anos ou mais (4) (5) & 18,3 & 11,5 & 36,4 & 11,1 & 11,6 & 16,6 \\
& & & & & & \\
Branca (5) & 12,1 & 10,3 & 30,9 & 8,3 & 9 & 12 \\
7 a 9 anos & 24,7 & 32,1 & 58,4 & 16,8 & 15,3 & 26 \\
10 anos ou mais (5) & 11 & 8 & 28 & 7,6 & 8,5 & 10,7 \\
10 a 14 anos & 6,6 & 6,5 & 25,1 & 2,4 & 2,4 & 5,8 \\
15 anos ou mais (5) & 11,6 & 8,2 & 28,6 & 8,4 & 9,4 & 11,5 \\
& & & & & & \\
Preta (5) & 30,1 & 18,1 & 50,4 & 20,3 & 19,1 & 34,5 \\
7 a 9 anos & 50,3 & 50,8 & 72,1 & 35,6 & 34,6 & 62,3 \\
10 anos ou mais (5) & 28,5 & 16,1 & 48,4 & 19,3 & 17,7 & 32,1 \\
10 a 14 anos & 19,6 & 26,2 & 41,3 & 7,4 & 4,4 & 24,3 \\
15 anos ou mais (5) & 29,9 & 14 & 49,7 & 21 & 20,1 & 33,2 \\
& & & & & & \\
Parda (5) & 29,3 & 15,7 & 41,8 & 16,4 & 21,7 & 22,1 \\
7 a 9 anos & 54,3 & 43,3 & 71,9 & 31,9 & 29,6 & 46,5 \\
10 anos ou mais (5) & 26,5 & 12,5 & 38,2 & 14,9 & 21 & 19,4 \\
10 a 14 anos & 22,5 & 11,3 & 35,5 & 7,3 & 5,9 & 14,1 \\
15 anos ou mais (5) & 27,4 & 12,8 & 38,8 & 16,3 & 23,9 & 20,5 \\
\end{tabular}

(1) Exclusive os dados da zona rural de Rondônia, Acre, Amazonas, Roraima, pará e Amapá.

(2) Exclusive os dados do Tocantins e da zona rural de Rondônia, Acre, Amazonas, Roraima, Pará e Amapá.

(3) Inclusive os dados de Tocantins.

(4) Inclusive as pessoas de cor amarela e sem declaração de cor.

(5) Inclusive.as pessoas de idade ignorada

Fonte: Ibge, Diretoria de Pesquisas, Departamento de Emprego e Rendimento, Pesquisa Nacional por Amostra de Domicílios. 
Tabela 4

Esperança de vida ao nascer, por sexo, segundo as Grandes Regiões

Brasil, 1980-1990

\begin{tabular}{|c|c|c|c|c|c|c|}
\hline \multirow[b]{2}{*}{ Grandes Regiōes } & \multicolumn{6}{|c|}{ Esperança de vida ao nascer } \\
\hline & Total & $\begin{array}{r}1980 \\
\text { Homens }\end{array}$ & Mulheres & Total & $\begin{array}{l}1990 \\
\text { Homens }\end{array}$ & Mulheres \\
\hline Brasil & 61,98 & 59,17 & 64,91 & 65,49 & 62,14 & 68,98 \\
\hline Norte & 61,31 & 57,92 & 64,83 & 67,35 & 63,82 & 71,01 \\
\hline Nordeste & 58,71 & 56,03 & 61,50 & 64,22 & 60,84 & 67,74 \\
\hline Sudeste & 64,54 & 61,20 & 68,01 & 67,53 & 63,56 & 71,66 \\
\hline Sul & 65,34 & 62,09 & 68,72 & 68,68 & 65,00 & 72,51 \\
\hline Centro-Oeste & 63,47 & 60,50 & 66,56 & 67,80 & 64,30 & 71,45 \\
\hline
\end{tabular}

Nota: Esperança de vida ao nascer implícitas em tábuas de mortalidade preliminares construídas a partir da conciliação das mortalidades infantis com as mortalidades das demais idades derivadas das informações dos Censos Demográficos e do Registro Civil.

Fonte: Ibge, Diretoria de Pesquisas, Departamento de População.

Tabela 5

Esperança de vida ao nascer, segundo as classes . de rendimento mensal familiar Brasil, 1984

\begin{tabular}{|c|c|c|c|c|c|c|c|c|c|}
\hline \multirow{3}{*}{$\begin{array}{l}\text { Classes de } \\
\text { rendimento } \\
\text { mensal familiar }\end{array}$} & \multirow[b]{3}{*}{ Total } & \multirow{3}{*}{$\begin{array}{l}\text { Brasil } \\
\text { Urbano }\end{array}$} & \multirow[b]{3}{*}{ Rural } & \multicolumn{5}{|c|}{ Esperança de vida ao nascer (anos) } & \multirow[b]{2}{*}{ este } \\
\hline & & & & & gião Nor & leste & & gião Sud & \\
\hline & & & & Total & Urbano & Rural & Total & Urbano & Rural \\
\hline $\begin{array}{l}\text { Até } 1 \text { salário } \\
\text { mínimo }\end{array}$ & 575 & $58 ?$ & 560 & 515 & 500 & 518 & 663 & 654 & 674 \\
\hline $\begin{array}{l}\text { Mais de } 1 \text { a } 2 \\
\text { salários mínimos }\end{array}$ & 62,0 & 63,4 & 59,8 & 53,7 & 54,9 & 52,5 & 67,8 & 67,0 & 70,0 \\
\hline $\begin{array}{l}\text { Mais de } 2 \text { a } 3 \\
\text { salários mínimos }\end{array}$ & 67,6 & 69,2 & 62,7 & 60,7 & 65,3 & 53,5 & 70,3 & 70,5 & 64,5 \\
\hline $\begin{array}{l}\text { Mais de } 3 \text { a } 5 \\
\text { salários mínimos }\end{array}$ & 69,7 & 70,3 & 66,7 & 63,6 & 64,5 & 61,1 & 71,2 & 71,2 & 71,5 \\
\hline $\begin{array}{l}\text { Mais de } 5 \\
\text { salários mínimos }\end{array}$ & 73,4 & 73,3 & 71,3 & 67,4 & 68,5 & 61,9 & 75,0 & 74,6 & 68,7 \\
\hline
\end{tabular}

Fonte: Ibge, Diretoria de Pesquisas, Departamento de Emprego e Rendimento, Pesquisa Nacional por Amostra de Domicílios - Pnad, 1984. 
Tabela 6

Taxa de mortalidade infantil, por sexo, segundo as Grandes Regiões

Brasil, 1980-1990

\begin{tabular}{lrrrrrr}
\hline & \multicolumn{6}{c}{ Taxa de mortalidade infantil (\%00) } \\
Grandes Regiões & Total & 1980 & Homens & Mulheres & Total & 1990 \\
& Homens & Mulheres \\
\hline Brasil & 65,8 & 72,9 & 58,4 & 51,6 & 58,7 & 44,3 \\
$\quad$ Norte & 62,8 & 69,9 & 55,5 & 53,2 & 60,3 & 45,9 \\
Nordeste & 106,8 & 114,6 & 98,8 & 88,2 & 95,6 & 80,6 \\
Sudeste & 47,4 & 54,4 & 40,0 & 30,0 & 37,0 & 22,8 \\
Sul & 43,7 & 50,8 & 36,3 & 26,7 & 33,6 & 19,6 \\
Centro-Oeste & 47,9 & 54,9 & 40,5 & 33,0 & 40,0 & 25,6 \\
\hline
\end{tabular}

Nota: Estimativas preliminares, conciliando indicadores de mortalidade infantil que utilizam informações dos Censos Demográficos e das Pesquisas nacionais por Amostra de Domicílios.

Fonte: Ibge, diretoria de Pesquisas, Departamento de População.

Tabela 7

Número de pessoas servidas por água, instalação sanitária e coleta de lixo Brasil, 1990

\begin{tabular}{|c|c|c|c|c|c|c|}
\hline \multirow{3}{*}{ Serviço domiciliar } & \multirow{3}{*}{\multicolumn{2}{|c|}{$\begin{array}{c}\text { Total } \\
\text { Absoluto Relativo } \\
(\%)\end{array}$}} & \multirow{2}{*}{\multicolumn{2}{|c|}{ Pessoas servidas }} & \\
\hline & & & & & $\mathrm{Ru}$ & Iral \\
\hline & & & Absoluto & $\begin{array}{c}\text { Relativo } \\
(\%)\end{array}$ & Absoluto & $\begin{array}{c}\text { Relativo } \\
(\%)\end{array}$ \\
\hline Total de pessoas (1) & 147,30 & 100,00 & 109,10 & 100,00 & 38,20 & 100,00 \\
\hline \multicolumn{7}{|l|}{ Água } \\
\hline \multicolumn{7}{|l|}{ Com canalização interna } \\
\hline Rede geral & 93,60 & 63,50 & 89,00 & 81,60 & 4,60 & 12,00 \\
\hline Outro & 12,70 & 8,60 & 3,70 & 3,40 & 9,00 & 23,60 \\
\hline \multicolumn{7}{|l|}{ Sem canalização interna } \\
\hline Rede geral & 10,70 & 7,30 & 9,20 & 8,40 & 1,50 & 3,90 \\
\hline Outro & 30,30 & 20,60 & 7,20 & 6,60 & 23,10 & 60,50 \\
\hline \multicolumn{7}{|l|}{ Instalação sanitária } \\
\hline \multicolumn{7}{|l|}{ Uso exclusivo } \\
\hline Rede geral & 54,80 & 37,20 & 52,90 & 48,50 & 1,90 & 5,00 \\
\hline F́ossa séptica & 22,30 & 15,10 & 19,60 & 18,00 & 2,70 & 7,10 \\
\hline Outro & 43,10 & 9,30 & 27,30 & 25,00 & 15,80 & 41,40 \\
\hline Outro & 27,10 & 18,40 & 9,30 & 8,50 & 17,80 & 46,60 \\
\hline \multicolumn{7}{|l|}{ Destinação do lixo } \\
\hline Coletado & 89,90 & 61,00 & 85,60 & 78,50 & 4,30 & 11,30 \\
\hline Queimado ou enterrado & 22,20 & 15,10 & 9,40 & 8,60 & 12,80 & 33,50 \\
\hline Outro & 35,20 & 23,90 & 14,10 & 12,90 & 21,10 & 55,20 \\
\hline
\end{tabular}

(1) Exclusive ou sem declaração

Fonte: Ibge, Diretoria de Pesquisas, Departamento de Emprego e Rendimento, Pesquisa Nacional por Amostra de Domićlios - Pnad, 1990. 
Tabela 8

Evolução dos índices de concentração de renda

Brasil, 1960-1990

\begin{tabular}{lcccc}
\hline Ano & Coeficiente Gini & Índice & $10+/ 10-$ & Índice \\
\hline 1960 & 0,50 & 100 & 34 & 100 \\
1970 & 0,60 & 120 & 40 & 118 \\
1980 & 0,59 & 118 & 47 & 138 \\
1990 & 0,63 & 126 & 78 & 229 \\
\hline
\end{tabular}

Fonte: Barros Mendonça \& Rocha, 1993.

Tabela 9

Distribuição do rendimento de todos os trabalhadores da população ocupada, segundo classes de percentual

Brasil, 1981-1990

\begin{tabular}{|c|c|c|c|c|c|c|c|c|}
\hline \multirow{3}{*}{$\begin{array}{l}\text { Classes } \\
\text { de } \\
\text { Percentual }\end{array}$} & \multicolumn{8}{|c|}{ Distribuição do rendimento (\%) } \\
\hline & \multicolumn{4}{|c|}{ Na classe } & \multicolumn{4}{|c|}{ Acumulada } \\
\hline & 1981 & 1983 & 1986 & 1990 & 1981 & 1983 & 1986 & 1990 \\
\hline $10-$ & 0,90 & 1,00 & 1,00 & 0,80 & 0,90 & 1,00 & 1,00 & 0,80 \\
\hline 10 & 2,00 & 1,80 & 2,10 & 1,80 & 2,90 & 2,80 & 3,00 & 2,60 \\
\hline 10 & 3,00 & 2,80 & 2,70 & 2,30 & 5,90 & 5,60 & 5,70 & 4,90 \\
\hline 10 & 3,80 & 3,50 & 3,30 & 3,00 & 9,70 & 9,10 & 9,10 & 7.90 \\
\hline 10 & 4,80 & 4,30 & 4,40 & 4,10 & 14,50 & 13,40 & 13,50 & 12,10 \\
\hline 10 & 6,10 & 5,70 & 5,70 & 5,50 & 20,60 & 19,00 & 19,20 & 17,00 \\
\hline 10 & 7,80 & 7,40 & 7,40 & 7,50 & 28,40 & 26,50 & 20,60 & 25,10 \\
\hline 10 & 10,60 & 10,40 & 10,30 & 10,50 & 39,00 & 38,90 & 38,90 & 35,50 \\
\hline 10 & 16,10 & 16,60 & 15,90 & 16,40 & 55,10 & 53,40 & 52,70 & 51,90 \\
\hline $10+$ & 44,90 & 46,20 & 47,30 & 48,10 & 100,00 & 100,00 & 100,00 & 100,00 \\
\hline $5+$ & 31,90 & 33,00 & 33,90 & 34,40 & - & - & - & 一 \\
\hline $1+$ & 12,10 & 13,30 & 14,00 & 13,90 & - & - & - & - \\
\hline Índice de Gini & 0,5644 & 0,5835 & 0,5841 & 0,6024 & - & - & - & - \\
\hline Índice de Theil & 0,6359 & 0,6940 & 0,7176 & 0,7464 & - & - & - & - \\
\hline
\end{tabular}

Nota: Exclusive os sem rendimentos e os sem declaração de rendimento.

Fonte: Ibge, Diretoria de Pesquisas, Departamento de Emprego e Rendimento. 
Tabela 10

Indicadores selecionados da distribuição de renda da população economicamente ativa com rendimento não-nulo

Brasil, 1960-1990

\begin{tabular}{lrrrrr}
\hline $\begin{array}{l}\text { Extratos } \\
\text { renda }\end{array}$ & $\begin{array}{r}\% \text { Renda } \\
1960(1)\end{array}$ & $\begin{array}{r}\% \text { Renda } \\
1970(1)\end{array}$ & $\begin{array}{r}\% \text { Renda } \\
1980(1)\end{array}$ & $\begin{array}{r}\% \text { Renda } \\
1970(2)\end{array}$ & $\begin{array}{r}\% \text { Renda } \\
1990(2)\end{array}$ \\
\hline $20 \%$ inferiores & 3,5 & 3,2 & 3,2 & 2,9 & 2,3 \\
$20 \%$ seguintes & 8,1 & 6,8 & 6,6 & 6,6 & 4,9 \\
$20 \%$ seguintes & 13,8 & 10,8 & 9,9 & 10,1 & 9,1 \\
$20 \%$ seguintes & 20,2 & 17 & 17,1 & 17,6 & 17,6 \\
$20 \%$ superiores & 54,4 & 62,2 & 63,2 & 62,8 & 66,1 \\
& & & & & 47,8 \\
$10 \%$ superiores & 39,7 & 47,8 & 47,8 & 46,8 & 49,7 \\
$5 \%$ superiores & 27,7 & 34,9 & 34,9 & 33,8 & 35,8 \\
$1 \%$ superior & 12,1 & 14,6 & 18,2 & 13,8 & 14,6 \\
Índice de Gini & 0,500 & 0,568 & 0,590 & 0,580 & 0,615 \\
& & & & & \\
R 1/40(3) & 1,048 & 1,460 & 1,862 & 1,453 & 2,012 \\
\hline
\end{tabular}

(1) Censos Demográficos (1960 e 1970 de Langoni, 1973, tabelas 3,5 e 3,6, 1980 de Bonelli \& Malen, 1984.

(2) Pnad anuais, não diretamente compativeis com censos.

(3) Razão entre a renda dos $1 \%$ mais rico e dos $40 \%$ mais pobres.

Tabela 11

Número de pobres e incidência da pobreza absoluta Brasil, 1980-1990

\begin{tabular}{lcccc}
\hline & \multicolumn{2}{c}{$\begin{array}{c}\text { Número de pessoas } \\
\text { (1000 pessoas) }\end{array}$} & \multicolumn{2}{c}{ Proporção de pobres } \\
Área & 1980 & 1990 & 1980 & 1990 \\
\hline Total & $29.477,00$ & $39.208,90$ & 34,80 & 27,00 \\
Urbano & $10.792,20$ & $19.057,20$ & 13,90 & 17,70 \\
Rural & $18.654,80$ & $20.151,70$ & 50,10 & 53,40 \\
\hline
\end{tabular}

Fonte: Tolosa \& Rocha, Políticas de Combate à Pobreza: Experiências e Equívocos.

São Paulo, Inae, Fórum Nacional, maio 1993. 
Probabilidades* de domicílios serem de pobres indigentes ou de pobres estruturais, segundo a sua estrutura familiar Brasil Uibano e Rural, 1989

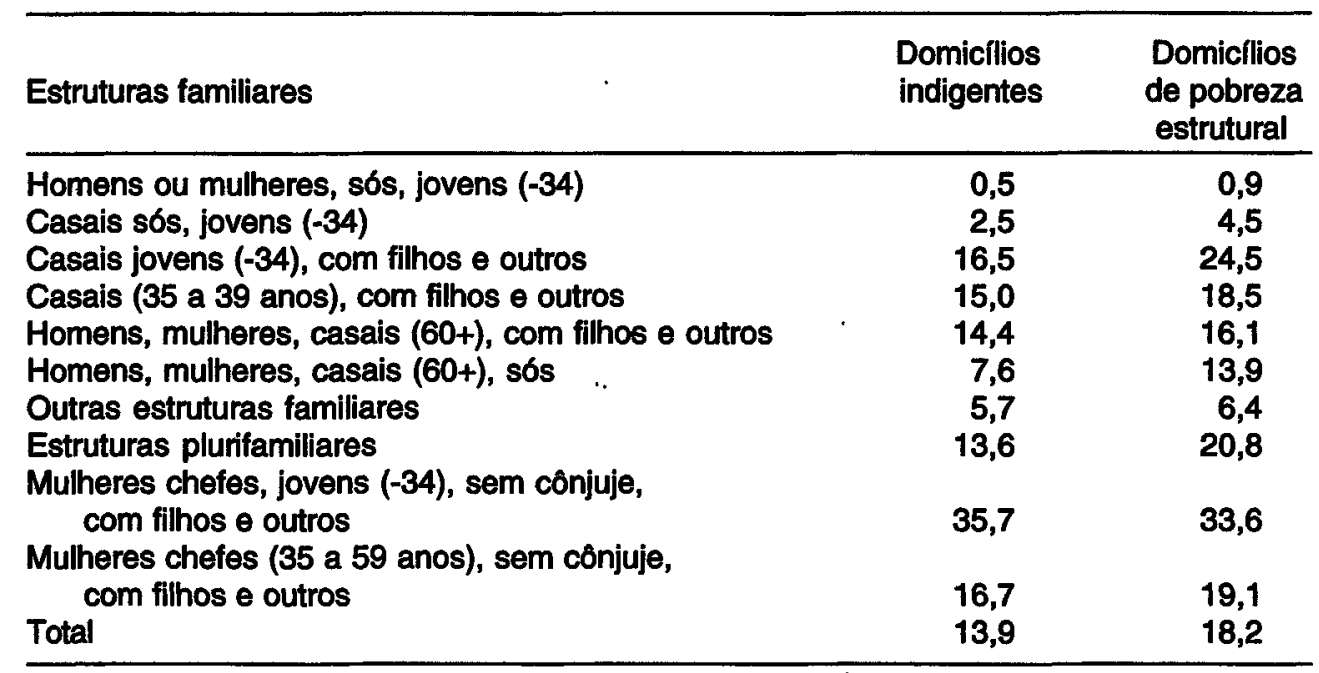

* Porcentagem sobre o total de domicllios de cada tipo de estrutura familiar.

Fonte: Pnsn; elaboração Nepp/Unicamp, 1994.

Tabela 13

Indicadores de educação

Brasil, 1981-1990

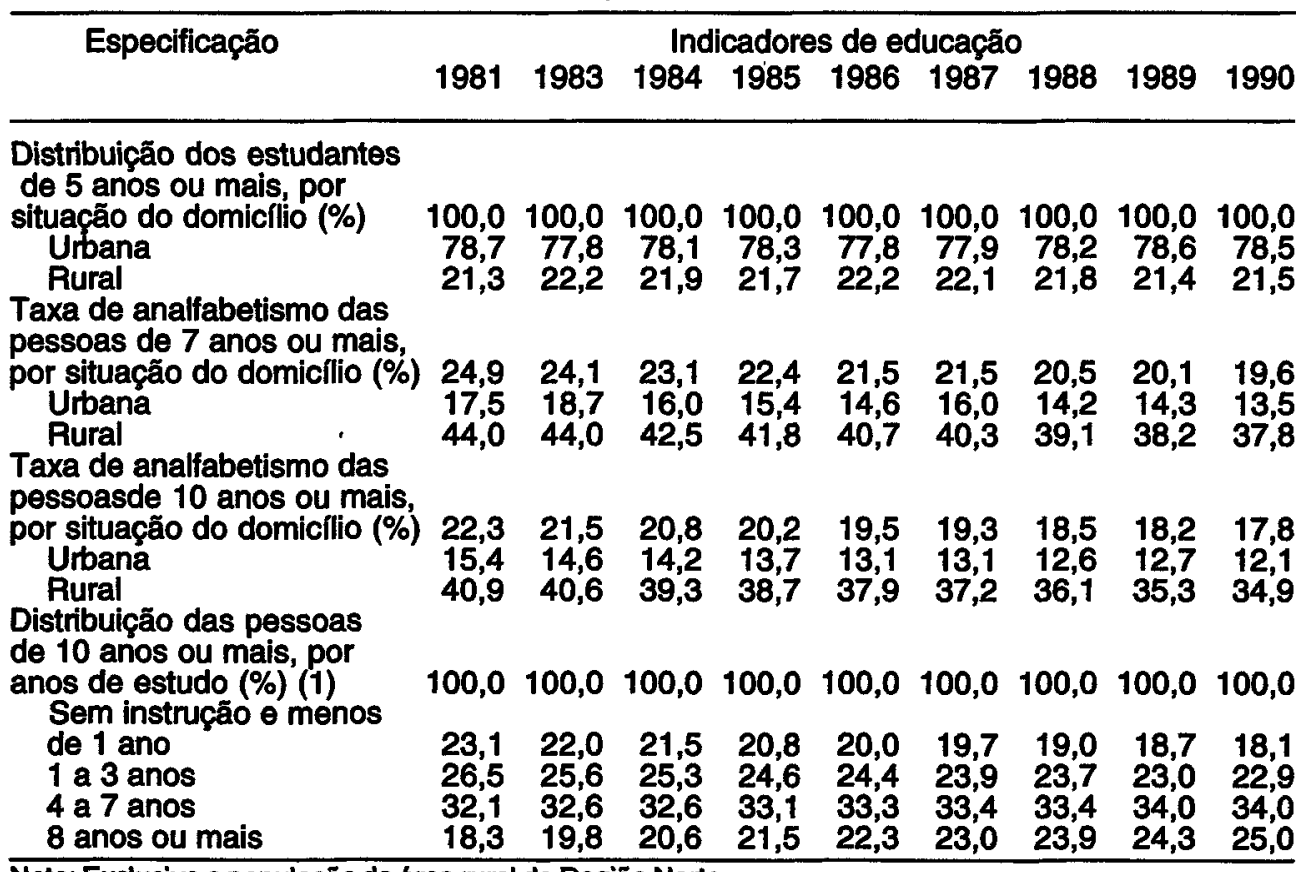

Nota: Exclusive a populaçăo da área rural da Regiăo Norte

(1) Inclusive as pessoas com anos de estudo não determinados e sem declaração.

Fonte: Ibge, diretoria de Pesquisas, Departamento de Empregos e Rendimentos, Pesquisa Nacional por Amostra de Domićlios - Pnad vários anos. 
Tabela 14

Domicílios rurais e urbanos, segundo várias regiōes

(em milhares)

Brasil, 1989

\begin{tabular}{lcrc}
\hline Domicílios & Pobres & Totais & \% Pobres \\
\hline Urbanos & & & \\
Norte e Centro-Oeste & 1.188 & 2.725 & 44 \\
Nordeste & 2.702 & 5.048 & 54 \\
Sudeste & 3.846 & 13.950 & 28 \\
Sul & 881 & 3.963 & 22 \\
Total Urbano & 8.617 & 25.686 & 34 \\
Rurais & $3.174^{\star *}$ & 7.073 & $45^{\star *}$ \\
\hline
\end{tabular}

* A zona rural da região Norte não foi coberta pelo Pnsn e, além disso, não havia dados suficientes para calcular-se a linha de pobreza rural para o Centro-Oeste; assim, estão incluídas aqui só as regiōes Nordeste, Sudeste e Sul.

** Provavelmente muito subestimadas

Fonte: Pnsn; elaboração Nepp/Unicamp, 1993

Tabela 15

Distribuição dos domicílios segundo indicador de

necessidades básicas e segundo níveis de pobreza

Brasil Urbano, 1989.

\begin{tabular}{lrrrrr}
\hline & $\begin{array}{l}\text { Indicador de } \\
\text { necessidades } \\
\text { básicas }\end{array}$ & I (1) & Pn (1) & NP (1) & Total \\
\hline $\begin{array}{l}\text { Número de } \\
\begin{array}{l}\text { Domicílios } \\
\text { (milhares) }\end{array}\end{array}$ & NBI & $1.503,00$ & $1.707,70$ & $1.624,90$ & $4.835,60$ \\
Distribuição & $1.324,20$ & $4.069,00$ & $15.394,70$ & $20.787,90$ \\
$\begin{array}{l}\text { Percentual } \\
\text { dos domicílios }\end{array}$ & NBI & 5,90 & 6,70 & 6,30 & 18,90 \\
\hline
\end{tabular}

(1) I - Indigentes; Pn - Pobres não indigentes; e NP - Não pobres.

(2) $\mathrm{NBI}$ - Necessidades básicas insatisfeitas.

NBS - Necessidades básicas satisfeitas.

Fonte: Pnsn, elaboração Nepp/Unicamp, 1993. 
Tabela 16

Distribuição percentual de dados básicos segundo níveis de indigência e pobreza, pelas várias regiões

Brasil Urbano, 1989

\begin{tabular}{lrrrrr}
\hline & \multicolumn{1}{c}{${ }^{*} \mathrm{Pn}^{*}$} & $\mathrm{NP}^{*}$ & Total & Total (milhares) \\
\hline Região Norte e Centro-oeste & & & & \\
Domicílios & 13,4 & 30,2 & 56,4 & 100 & $2.725,40$ \\
Pessoas & 16,2 & 33,1 & 50,7 & 100 & $12.222,80$ \\
Crianças (0 a 3) & 23,0 & 34,3 & 42,7 & 100 & $1.206,30$ \\
& & & & & \\
Região Nordeste & & & & & \\
Domicílios & 23,0 & 30,5 & 46,5 & 100 & $5.048,30$ \\
Pessoas & 29,4 & 29,7 & 40,9 & 100 & $23.307,10$ \\
Crianças (0 a 3) & 40,8 & 27,6 & 31,6 & 100 & $2.203,20$ \\
& & & & & \\
Região Sudeste & & & & & \\
Domicílios & 7,5 & 20,1 & 72,4 & 100 & $13.949,60$ \\
Pessoas & 8,4 & 23,1 & 68,5 & 100 & $53.988,60$ \\
Crianças (0 a 3) & 16,9 & 28,8 & 54,3 & 100 & $4.259,80$ \\
Região Sul & & & & & \\
Domicílios & & & & & \\
Pessoas & 6,6 & 15,6 & 77,8 & 100 & $3.963,20$ \\
Crianças (0 a 3) & 7,8 & 17,4 & 74,8 & 100 & $14.964,40$ \\
Total Urbano & 11,6 & 22,2 & 66,2 & 100 & $1.209,90$ \\
Domicílios & & & & & \\
Pessoas & 11,0 & 22,5 & 66,5 & 100 & $25.686,50$ \\
Crianças (0 a 3) & 13,9 & 24,9 & 61,2 & 100 & $104.482,90$ \\
\hline
\end{tabular}

*I-Indigentes; Pn - Pobres não indigentes, e NP - Não pobres.

Fonte: Pnsn; elaboração Nepp/Unicamp.

Tabela 17

Distribuição percentual de pobres em nível de indigência e dos pobres estruturais, pelo contínuo urbano-rural Brasil Urbano e Rural, 1989.

\begin{tabular}{lrr}
\hline Localização & $\begin{array}{r}\text { \% Pobres } \\
\text { indigentes }\end{array}$ & $\begin{array}{r}\text { \% Pobres } \\
\text { estruturais }\end{array}$ \\
\hline Urbano & & \\
$\quad$ Metropolitano & 15,3 & 13,2 \\
Não Metropolitano & 40,1 & 39,5 \\
Subtotal & 55,4 & 52,7 \\
Rural & 44,6 & 47,3 \\
& 100,0 & 100,0 \\
Total (milhares) & $24.739,10$ & $32.235,00$ \\
\hline
\end{tabular}

Fonte: Pnsn; elaboração Nepp/Unicamp, 1994. 


\section{Tabela 18}

Distribuição de pobres em nível de indigência $\Theta$ dos pobres estruturais, por regiões

Brasil Urbano e Rural*, 1989.

\begin{tabular}{lccc}
\hline $\begin{array}{l}\text { Localização } \\
\text { regional }\end{array}$ & $\begin{array}{c}\text { Pobres } \\
\text { indigentes (\%) }\end{array}$ & $\begin{array}{c}\text { Pobres } \\
\text { estruturais (\%) }\end{array}$ & $\begin{array}{r}\text { População } \\
\text { total (\%) }\end{array}$ \\
\hline $\begin{array}{l}\text { Urbano } \\
\text { Norte }\end{array}$ & 3,60 & & \\
Nordeste & 25,80 & 4,20 & 3,50 \\
Sudeste & 16,90 & 21,10 & 17,00 \\
Sul & 4,70 & 18,10 & 39,70 \\
Centro-Oeste & 4,30 & 4,10 & 10,90 \\
Total & 55,30 & 5,20 & 5,50 \\
& & 52,70 & 76,60 \\
Rural & 33,00 & - & 13,30 \\
$\quad$ Nordeste & 5,90 & 34,50 & 6,70 \\
Sudeste & 5,70 & 6,90 & 5,30 \\
Sul & 44,60 & 5,90 & 25,30 \\
Total & & 47,30 & $138.195,80$ \\
Total (milhares) & $24.739,10$ & $32.235,00$ & \\
\hline
\end{tabular}

* A zona rural da região Norte não foi coberta pelo Pnsn e, além disso, não havia dados suficientes para calcular-se a linha de pobreza rural para o Centro-Oeste; assim, estão incluídas aqui só as regiões Nordeste, Sudeste e Sul.

Fonte: Pnsn; elaboração Nepp/Unicamp, 1994.

Tabela 19

Índices de evolução do PIB, PIB per capita e salário mínimo

\begin{tabular}{lccc}
\hline Ano & $\begin{array}{c}\text { PIB } \\
\text { Per Capita } \\
(1)\end{array}$ & $\begin{array}{c}\text { PIB } \\
(1)\end{array}$ & $\begin{array}{c}\text { Salário } \\
\text { Mínimo } \\
(2)\end{array}$ \\
\hline 1980 & 100,0 & 100,0 & 100,0 \\
1981 & 93,7 & 95,5 & 98,7 \\
1982 & 92,4 & 96,1 & 99.1 \\
1983 & 87,6 & 92,7 & $87, .9$ \\
1984 & 90,4 & 97,6 & 91,2 \\
1985 & 95,7 & 105,4 & 83,9 \\
1986 & 101,1 & 113,4 & 82,3 \\
1987 & 102,2 & 117,4 & 64,1 \\
1988 & 99,9 & 117,3 & 64,2 \\
1989 & 102,0 & 121,2 & 69,7 \\
1990 & 95,7 & 115,8 & 48,0 \\
1991 & 94,9 & 117,2 & 55,1 \\
1992 & 92,3 & 116,1 & 47,3 \\
\hline
\end{tabular}

(1) Fonte: Ipea.

(2) Fonte: Sabóia, J. L. M. - Evolução do salário mínimo no Brasil. 
Tabela 20

Taxa de desemprego aberto

Brasil, 1991-1993 (1)

\begin{tabular}{lc}
\hline \multicolumn{1}{c}{ Meses } & Taxa Média (\%) \\
\hline $\begin{array}{l}1991 \\
\text { Janeiro }\end{array}$ & \\
Dezembro & 4,9 \\
& 4,1 \\
1992 & \\
Janeiro & \\
Dezembro & 4,9 \\
& 4,5 \\
1993 & \\
Janeiro & \\
Fevereiro & \\
Março & 6,0 \\
Abril & 5,8 \\
Maio & 5,9 \\
Junho & 6,1 \\
Julho & - \\
Agosto & - \\
Setembro & 5,2 \\
Outubro & 5,3 \\
Novembro & 5,1 \\
Dezembro & 4,9 \\
\hline
\end{tabular}

(1) Obtida da relação entre o número de pessoas que estava procurando emprego ou aguardando o resultado de proposta para ingresso no trabalho à época da pesquisa e o número de pessoas economicamente ativas (PEA), com idade igual ou superior a 15 anos, nas seis principais regiōes metropolitanas do país: Rio de Janeiro, Belo Horizonte, Porto Alegre, São Paulo, Recife e Salvador.

Fonte: lbge. 
Tabela 21

Distribuição dos empregados no trabalho principal, por categoria do emprego, segundo as Grandes Regiões e as Unidades da Federação

Brasil, 1990

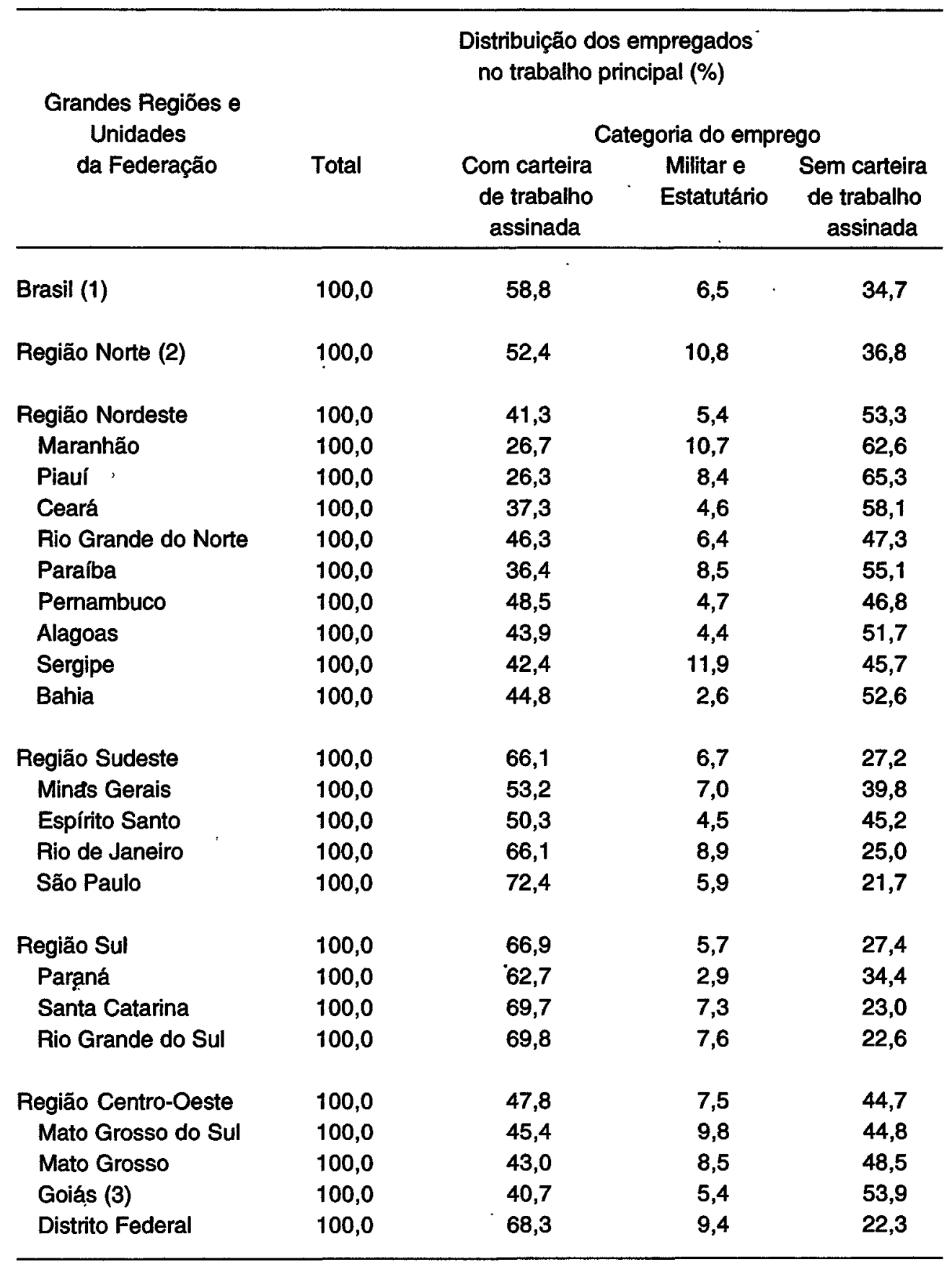

(1) Exclusive o rendimento da população ocupada da área rural da antiga região Norte.

(2) Exclusive a população empregada de Tocantins e da área Rural.

(3) Inclusive a população empregada de Tocantins.

Fonte: Ibge, Pesquisa Nacional por Amostra de Domicílios. 
Tabela 22

Evolução da composição setorial da ocupação

Brasil, 1981-1990

\begin{tabular}{|c|c|c|c|c|c|c|}
\hline \multirow[b]{2}{*}{ Ano } & \multicolumn{6}{|c|}{ - Setor } \\
\hline & Agricultura & Indústria & $\begin{array}{c}\text { Construção } \\
\text { civil }\end{array}$ & $\begin{array}{l}\text { Administração } \\
\text { pública }\end{array}$ & $\begin{array}{l}\text { Serviços } \\
\text { privados }\end{array}$ & $\begin{array}{l}\text { Setor } \\
\text { financeiro }\end{array}$ \\
\hline $\begin{array}{l}1981 \\
1982 \\
1983 \\
1984 \\
1985 \\
1986 \\
1987 \\
1988 \\
1989 \\
1990\end{array}$ & $\begin{array}{l}24,89 \\
25,08 \\
22,58 \\
25,78 \\
24,40 \\
22,63 \\
21,03 \\
20,79 \\
19,79 \\
19,27\end{array}$ & $\begin{array}{l}13,99 \\
13,88 \\
12,99 \\
13,28 \\
13,85 \\
14,90 \\
14,60 \\
14,34 \\
14,75 \\
14,19\end{array}$ & $\begin{array}{r}9,67 \\
8,58 \\
11,41 \\
\quad 6,93 \\
. \quad 6,90 \\
7,56 \\
7,77 \\
7,41 \\
7,28 \\
7,20\end{array}$ & $\begin{array}{l}11,79 \\
11,69 \\
11,95 \\
12,09 \\
12,36 \\
12,77 \\
13,06 \\
13,05 \\
13,72 \\
14,31\end{array}$ & $\begin{array}{l}10,88 \\
11,05 \\
11,16 \\
11,33 \\
11,54 \\
11,80 \\
11,88 \\
12,40 \\
12,22 \\
12,37\end{array}$ & $\begin{array}{l}2,81 \\
2,92 \\
3,11 \\
3,17 \\
3,28 \\
2,79 \\
2,84 \\
2,77 \\
2,91 \\
2,76\end{array}$ \\
\hline
\end{tabular}

Fonte: Urani, A., 1995, a partir de tabulações especiais da Pnad/lbge.

Tabela 23

Evolução da renda real por nível de escolaridade (Índice $1981=100$ )

\begin{tabular}{crrrrr}
\hline & \multicolumn{5}{c}{ Anos de estudo } \\
Ano & $<1$ & $1-4$ & $5-8$ & $9-11$ & $>11$ \\
\hline 1981 & 100,00 & 100,00 & 100,00 & 100,00 & 100,00 \\
1982 & 100,78 & 98,33 & 99,82 & 102,95 & 104,79 \\
1983 & 75,78 & 78,46 & 70,03 & 80,45 & 81,65 \\
1984 & 79,14 & 78,72 & 75,51 & 77,00 & 78,42 \\
1985 & 86,03 & 88,46 & 86,26 & 89,61 & 92,61 \\
1986 & 129,27 & 126,58 & 114,21 & 113,82 & 125,52 \\
1987 & 91,09 & 90,10 & 86,81 & 93,54 & 96,95 \\
1988 & 81,31 & 84,33 & 81,66 & 89,98 & 99,87 \\
1989 & 98,46 & 105,04 & 97,81 & 108,52 & 115,10 \\
1990 & 81,18 & 82,27 & 80,20 & 85,02 & 91,29 \\
\hline Fonte:Pnad/lbge. & & & & &
\end{tabular}

Tabela 24

Evolução da renda média por posição na ocupação (Índice $1981=100$ )

\begin{tabular}{|c|c|c|c|c|}
\hline \multirow[t]{2}{*}{ Ano } & \multirow[b]{2}{*}{ Com carteira } & \multicolumn{2}{|c|}{ Posição na ocupação } & \multirow[b]{2}{*}{ EmpregadoI } \\
\hline & & Sem carteira & Conta própria & \\
\hline $\begin{array}{l}1981 \\
1982 \\
1983 \\
1984 \\
1985 \\
1986 \\
1987 \\
1988 \\
1989\end{array}$ & $\begin{array}{r}100,00 \\
102,52 \\
81,51 \\
79,21 \\
90.26 \\
109,31 \\
92,29 \\
96,10 \\
102,39\end{array}$ & $\begin{array}{r}100,00 \\
106,96 \\
81,34 \\
83,07 \\
96,76 \\
138,35 \\
103,10 \\
98,00 \\
114,10\end{array}$ & $\begin{array}{r}100,00 \\
95,32 \\
85,90 \\
84,46 \\
98,51 \\
153,75 \\
107,49 \\
98,52 \\
128,87\end{array}$ & $\begin{array}{r}100,00 \\
102,09 \\
92,24 \\
91,24 \\
107,07 \\
166,11 \\
111,20 \\
106,70 \\
142,02\end{array}$ \\
\hline 1990 & 81,07 & 109,92 & 100,15 & 101,52 \\
\hline
\end{tabular}

Fonte: Pnad/lbge 
Tabela 25

Rendimento nominal médio mensal de trabalho das pessoas ocupadas, por cor e sexo das pessoas segundo as Grandes Regiões e as Unidades da Federação

Brasil, 1990

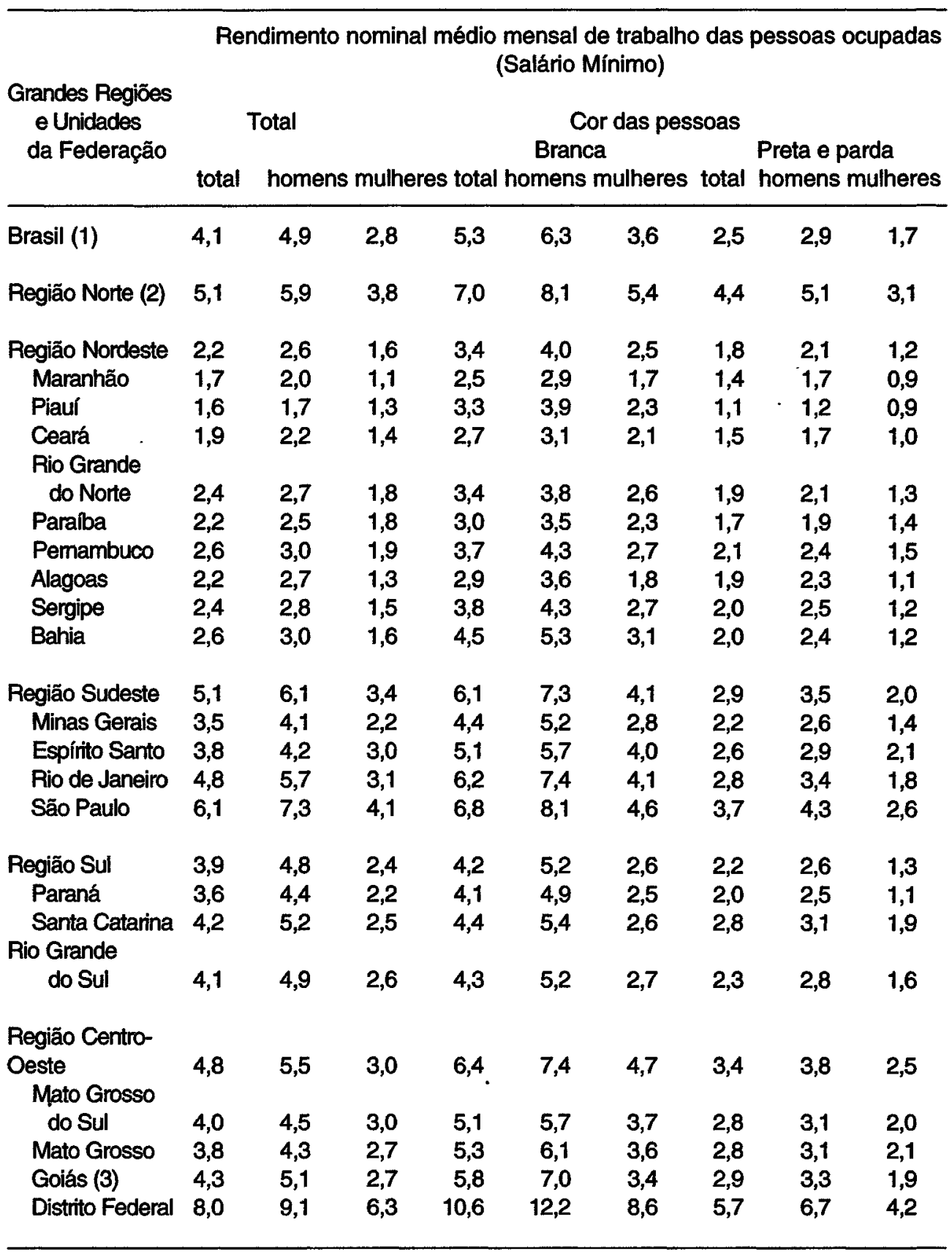

(1) Exclusive o rendimento da população ocupada da área rural da antiga região Norte.

(2) Exclusive o rendimento da população ocupada de Tocantins e da área rural.

(3) Inclusive o da população ocupada de Tocantins.

Fonte: Ibge, Pesquisa Nacional por Amostra de Domicilios. 


\section{Gráfico 1}

Proporção de domicílios urbanos com serviços adequados de água e instalação sanitária e coleta de lixo

Brasil, 1981-1990

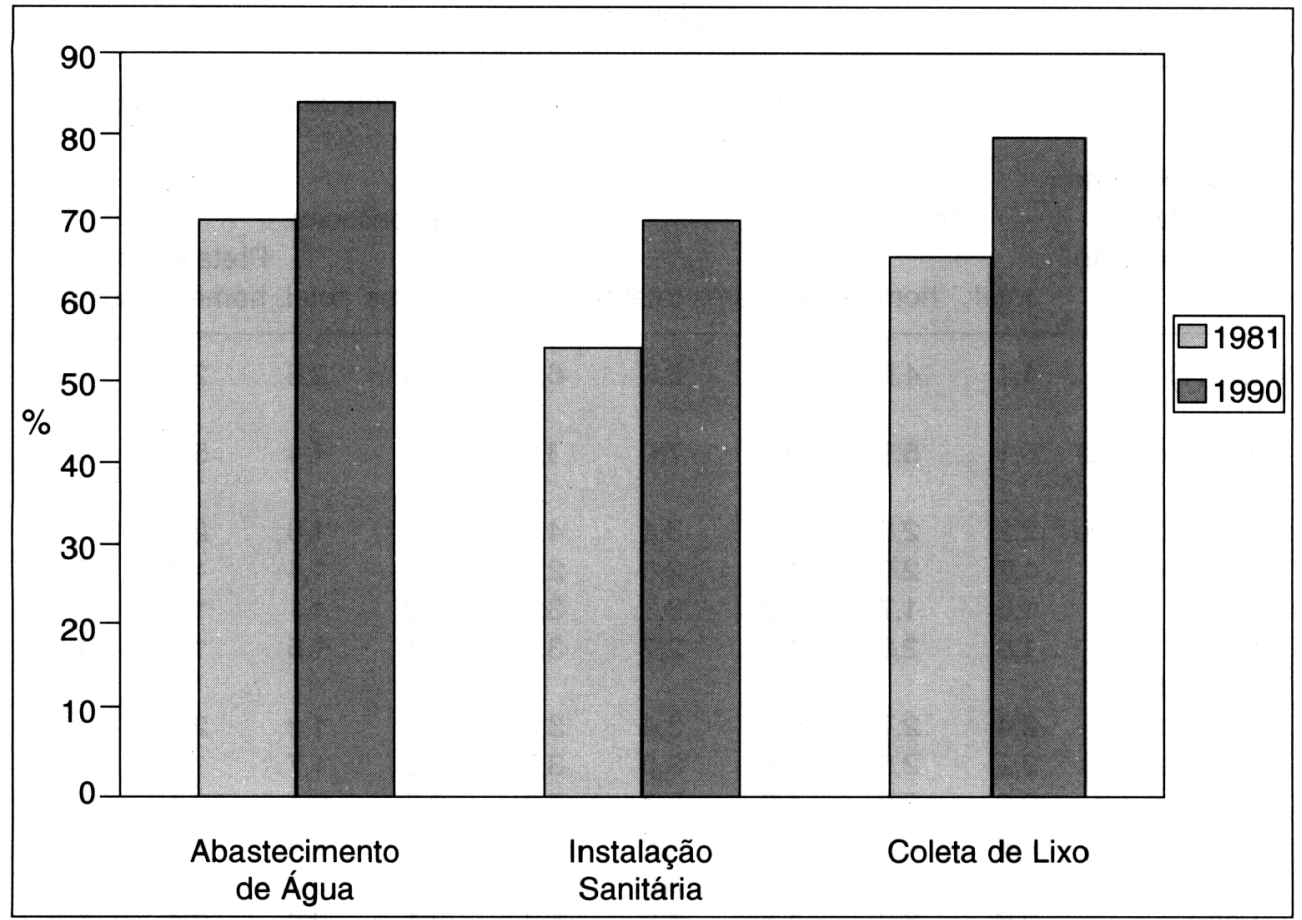

Fonte: Ibge, Diretoria de Pesquisas, Departamento de Estatísticas e Indicadores Sociais.

\section{Gráfico 2}

Declínio na taxa de analfabetismo entre a população de 10 anos e mais

Brasil, 1940-1991

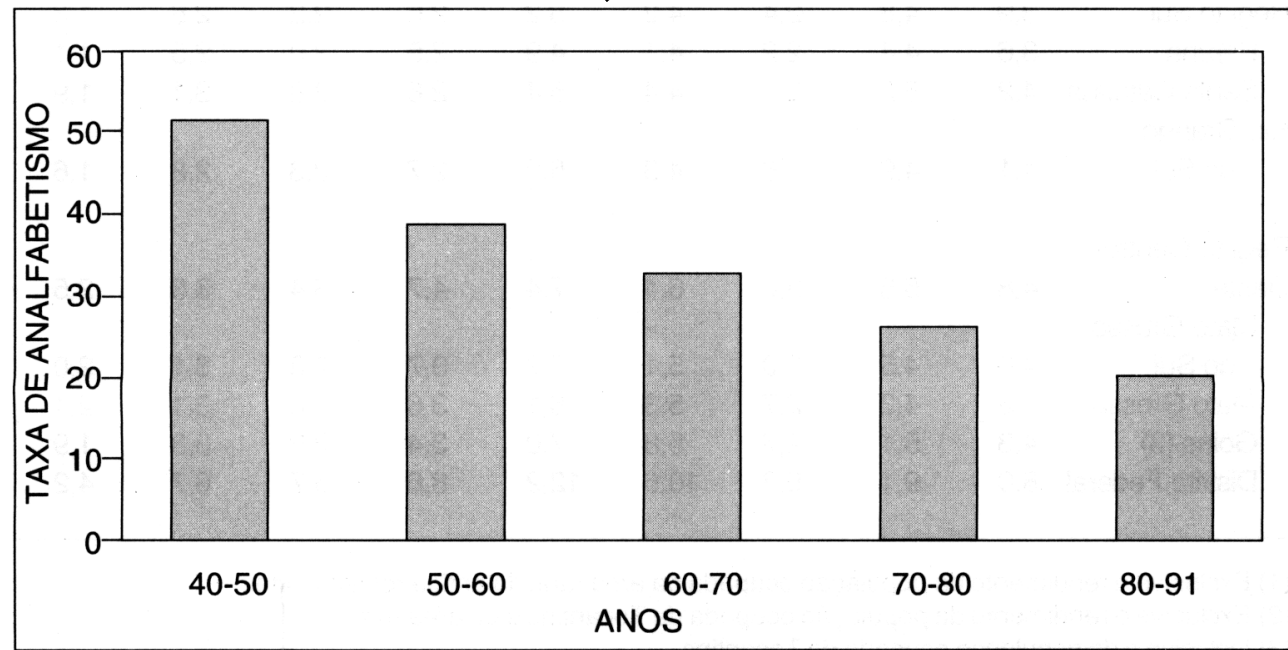

Fonte: Wanderley Guilherme dos Santos (org.), Que Brasil é este?, São Paulo, Vértice, 1990, p. 48 
Gráfico 3

Apropriação de renda pelos $10 \%$ mais ricos e

$50 \%$ mais pobres da PEA

Brasil, 1980-1991

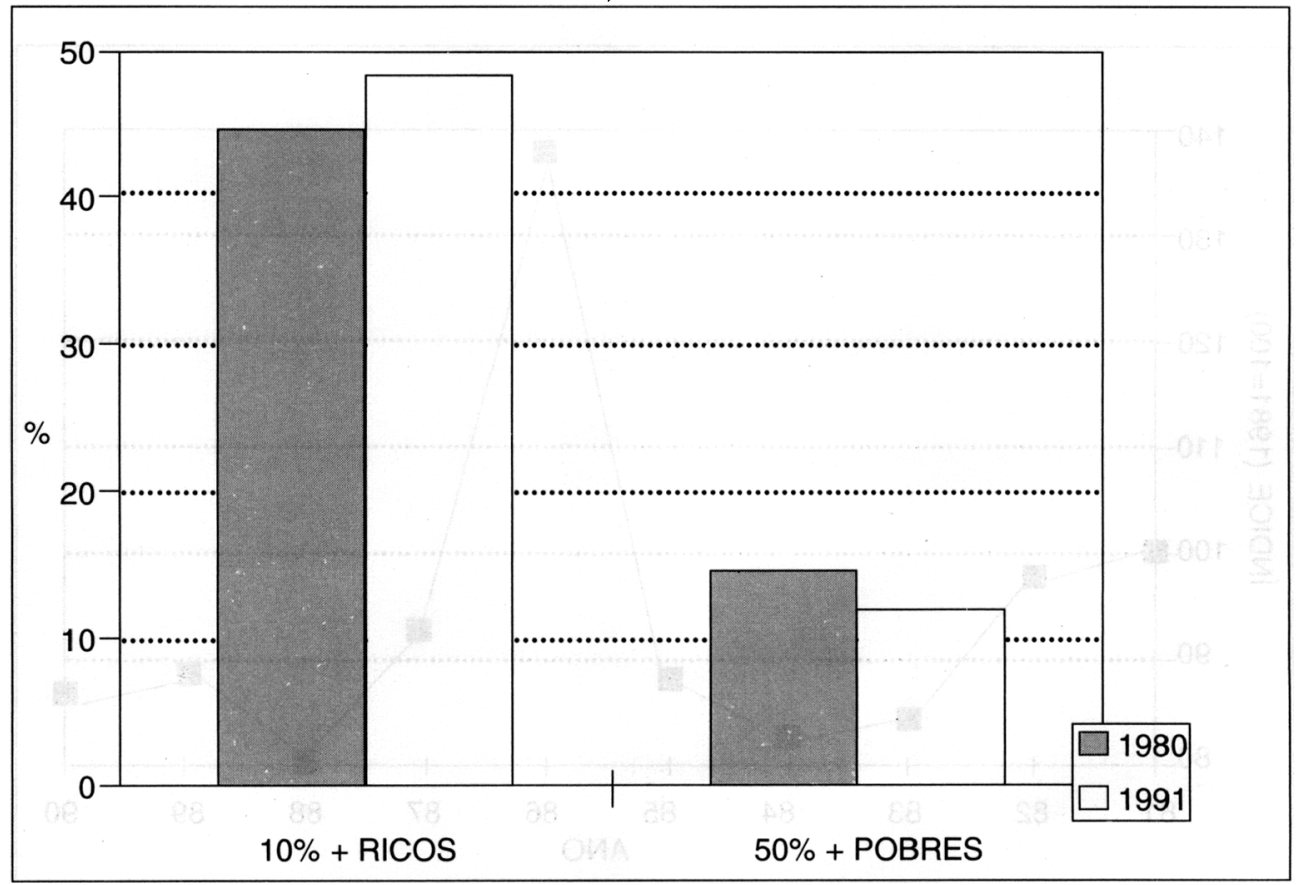

Fonte: Ibge, Diretoria de Pesquisas, Departamento de Emprego e Rendimento.

Gráfico 4

Taxa de Urbanização da População Brasileira

Brasil, 1940-1991

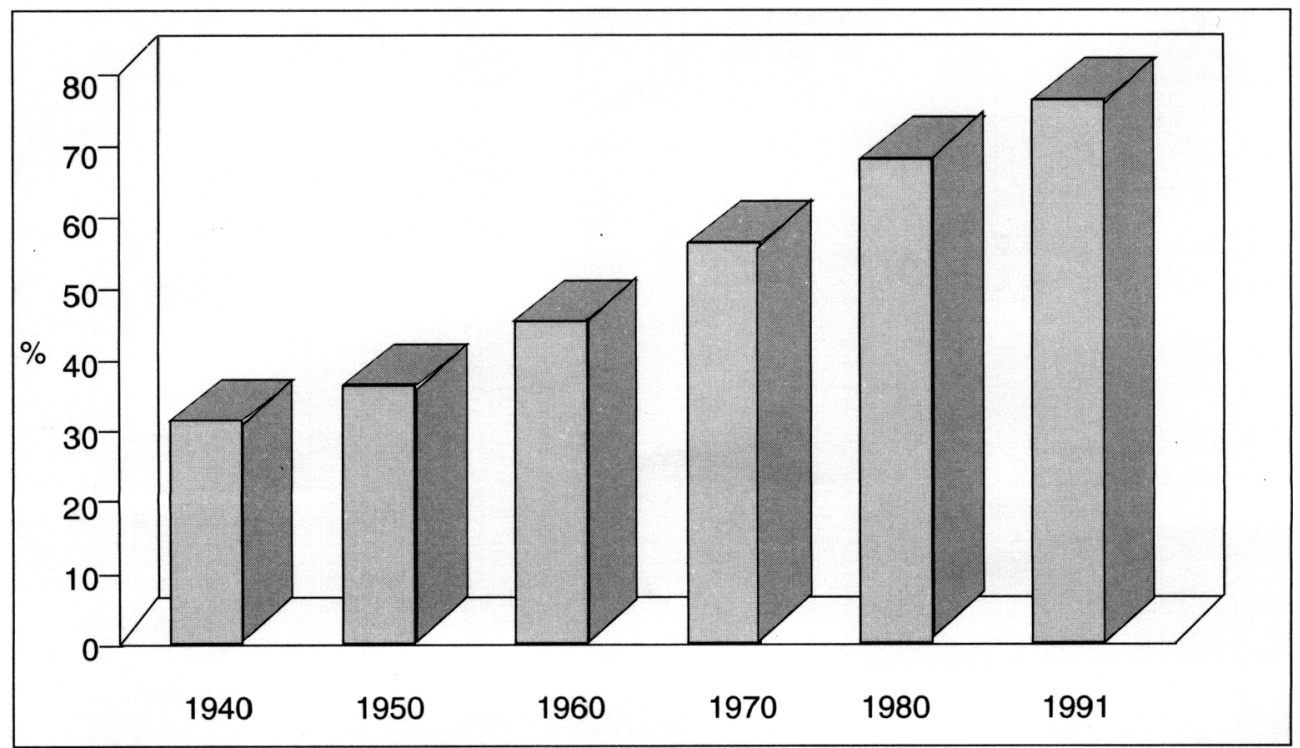

Fonte: lbge, Anuário Estatístico do Brasil, 1992 
Gráfico 5

Evolução do salário real médio

Brasil, 1981-1990

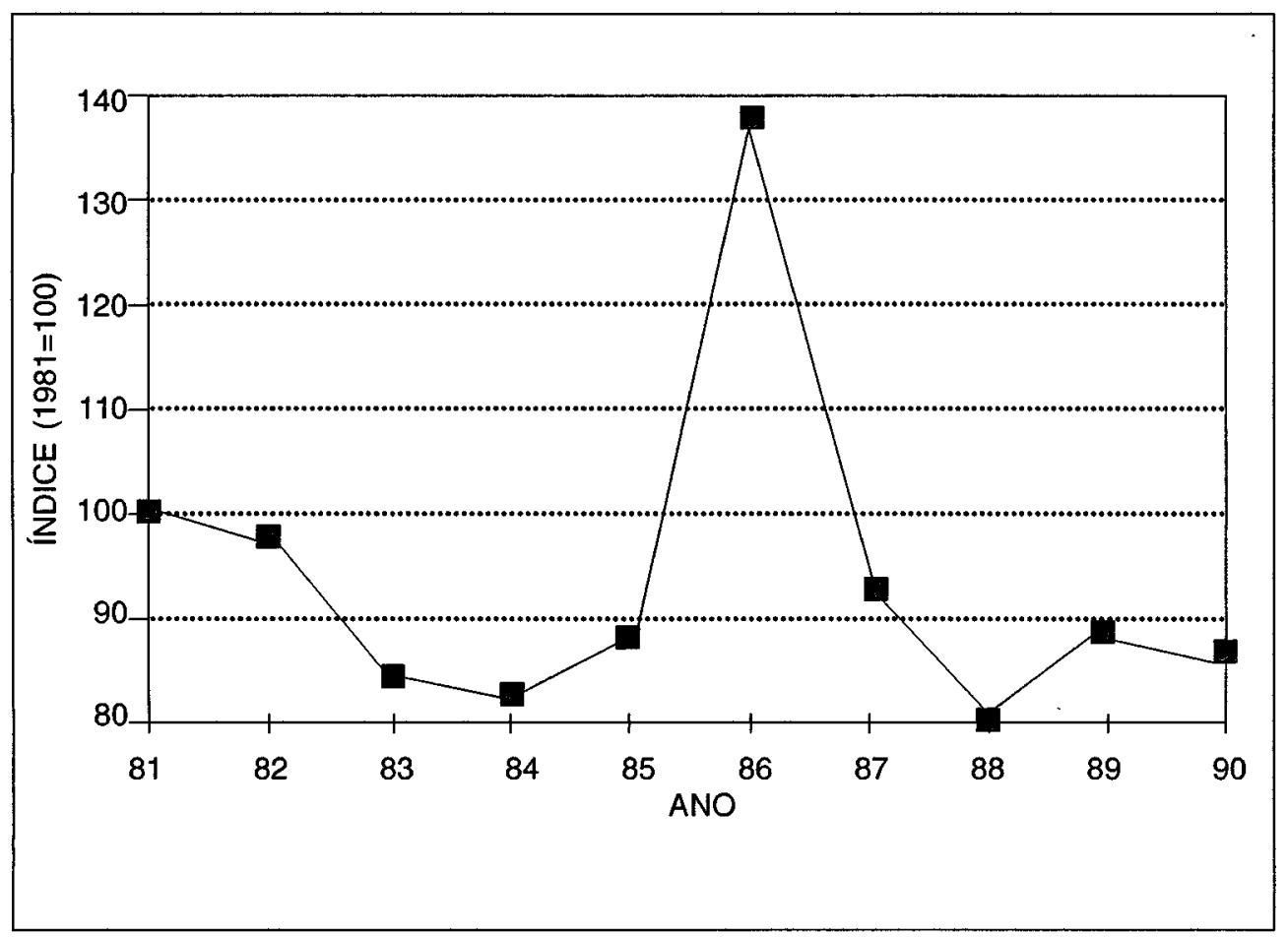

Fonte: Urani, A. 1995. A partir de tabulações especiais da Pnad. 